\title{
A new freshwater ostracod genus from the northern Neotropical Region and its phylogenetic position in the family Cyprididae (Podocopida)
}

Hyunsu Yoo ${ }^{\text {a) }}$, Sergio Cohuo ${ }^{\text {b,c) }}$, Laura Macario-Gonzalez ${ }^{\text {b,c })}$ and Ivana Karanovic ${ }^{\text {a,d)* }}$

a) Hanyang University, Department of Life Science, Colleague of Natural Sciences, 17

Haengdang-dong, Seongdonggu, Seoul 133-791, Korea

b) Institut für Geosysteme und Bioindikation, Technische Universität Braunschweig, Langer

Kamp 19c D-38106 Braunschweig, Germany

c) El Colegio de la Frontera Sur (ECOSUR), Unidad Chetumal, Av. Centenario km 5.5, Chetumal, 77014 Quintana Roo, Mexico

d) Institute of Marine and Antarctic Studies, University of Tasmania, Private Bag 49, 7001, Hobart, Tasmania, Australia

*corresponding author: ivana@ hanyang.ac.kr

Abstract

Manuelcypris n. gen., along with two species M. chetumalensis n. sp. and M. tabascena n. sp., are described from Southern Mexico. Another three species are transferred into the new genus: $M$. cisternina (Furtos, 1936) comb. nov., known from the Yucatan Peninsula, was originally described in the genus Eucypris Vávra, 1891, while M. punctata (Keyser, 1975) comb. nov., from Florida, and M. antillensis (Broodbakker, 1982) comb. nov., from the West Indies, were originally described in the genus Heterocypris Claus, 1892. The latter two new combinations are 
based only on the literature data, while for $M$. cisternina we examined its type material. The new genus is attributed to Cyprinotinae, but with an isolated position based on the absence of any seta on the basal segment of the walking leg and the reduced chaetotaxy of the fifth leg. The validity of this genus is confirmed with molecular markers, $18 \mathrm{~S}$ rDNA and $28 \mathrm{~S}$ rDNA which were used in the phylogenetic reconstruction along with several newly obtained sequences and others downloaded from the GenBank belonging to closely related taxa. Two methods, Maximum Parsimony and Maximum Likelihood, used in the analysis support the new genus with 100 bootstrap values. We also provide a taxonomic key for the five representatives of the new genus.

Key Words: 18S rDNA, 28S rDNA, Ostracoda, Manuelcypris n. gen., freshwater

\section{Abbreviations}

A1 - antennula; A2 - antenna; UR - uropodal ramus; H - height; L - length; LV - left valve; Md mandible; Mdp - mandibular palp; Mx - maxillula; RV - right valve; L5, L6, L7 - first, second and third thoracopods respectively; W - width.

\section{Introduction}

Ostracods of the family Cyprididae Baird, 1845 are the dominant group in open freshwater ecosystems, accounting for more than a half of the circa 2000 freshwater species described so far (Karanovic, 2012; Martens et al., 2008; Martens and Savatenalinton, 2011). The family comprises over 20 subfamilies most of which have a global distribution. Generally, endemism across zoogeographical provinces on the subfamily level is very rare in ostracods (Martens et al., 2008). In the family Cyprididae, a handful of families (i.e. Batucyprettinae, Herpetocyprellinae, Liocypridinae, Ngarawinae, Pelocypridinae) are each restricted to one zoogeographical province. 
This may, however, be the result of the lack of research or unresolved phylogenetical relationships. During 250 years since the first Cyprididae ostracod, Cypridopsis vidua (Müller, 1776) was described, systematics of this family became more complex and in the recent years several taxonomic and phylogenetic studies attempted to revise a few subfamilies and genera. For example, Martens (1989) and Martens et al. (1992) revised Eucypridinae and proposed several important taxonomic characters (such as, for example the presence of "c" seta on L5 and the length ration between $\mathrm{d} 1$ and $\mathrm{d} 2$ setae on L6) for distinguishing between genera; Martens (1986), and Martens $(1990,1992)$ revised Megalocypridinae and Cypridinae; Savatenalinton and Martens (2009) revised Cypricercinae, while Martens (2001) revised Herpetocypridinae. All these revisions were based on the morphological characters (both of the carapace and soft parts) and still a thorough revision of any of the subfamilies based on molecular markers is lacking. However, several studies included representatives of various Cyprididae subfamilies in the attempt to resolve phylogenetic relationships within ostracods in general or the positions of various genera within their respective subfamilies. In this regard, Yamaguchi and Endo (2003) used $18 \mathrm{~S}$ rDNA to study the molecular phylogeny of Ostracoda, while Yu et al. (2005) used the same marker and a very limited number of taxa to study phylogenetic relationship within Cypridocopina. More recently Kong et al. (2014) aimed to resolve the position of the genus Chrissia Hartmann, 1957 within Cyprididae, also by studying 18S rDNA. Their analysis was so far the most extensive in terms of the number of taxa they used, and it strongly supported monophyly only of a few Cyprididae subfamilies, while it disputed Herpetocypridinae, Eucypridinae and Cyprinotinae.

Cyprinotinae comprises five genera and over 100 named Recent species ( Martens and Savatenalinton, 2011) and as such it is one of the most specious Cyprididae subfamilies. Several species have a Holarctic distribution, and one, Heterocypris incongruens (Ramdohr, 1808), has a 
cosmopolitan distribution (Meisch, 2000), a variable carapace morphology and a high clonal diversity (Rossi et al., 1990). Although this species prefers shallow seasonal pools, it is very tolerant to various conditions, including high salinity (Meisch, 2000) and it displays a geographic parthenogenetic reproduction, sometimes with sexual and asexual populations inhabiting the same ecosystem (Rossi et al., 2007). As a result of its wide distribution, morphological variability, mixture of sexual and parthenogenetic reproduction, a number species may prove to be synonyms, but it is also possible that some of the records of $H$. incongruens actually apply to separate species. Studies to test a possible cryptic speciation in Heterocypris incongruens have never been carried out, but in another species, Eucypris virens (Jurine, 1820) with the same distribution, morphological variability and peculiar reproduction modes, a numerous potentially cryptic species have been reported from around the globe with divergence rates between mtCOI sequences approaching 20\% (see Bode et al., 2010). Eucypris virens belongs to Eucypridinae, which can be considered a sister group to Cyprinotinae. Representatives of the two subfamilies are indeed very similar and the two main differences are the presence of peculiar wart-shaped elevations on the frontal part of valves ("porenwarzen") in at least part of the species and presence of a " $\mathrm{c}$ " seta on the fifth leg in Eucypridinae. In addition, there is a tendency of a slender uropodal ramus and short posterior seta on the same appendage in comparison to Cyprinotinae. However, at least one species, Eucypris pigra (Fischer, 1851), lacks porenwarzen, has a robust uropodal ramus and a longer posterior uropodal seta. This species is thus more similar to Cyprinotinae.

The systematics of Eucypridinae has gone through many changes in the recent years (see references above), thanks to the advances in the taxonomic research. This often led to the new systematic combinations for taxa described decades ago, especially when studying less explored regions of the world, such as Central and South America. For example, Díaz and Martens (2014) 
described a Eucypridinae genus, Argentocypris Díaz and Martens, 2014 to include one new South American species and two species previously assigned to Eucypris and Cypris. In this paper we describe a new genus to accommodate two new species collected from southern Mexico, plus Eucypris cisternina Furtos, 1936 described from the same region (Furtos, 1936), Heterocypris punctata Keyser, 1975 originally described from Florida (Keyser, 1975) and H. antillensis Broodbakker, 1982 from the Antilles (Broodbakker, 1982). The characteristics of these five species place them into an intermediate position between Cyprinotinae and Eucypridinae and in order to test the position of the new genus we used two molecular markers, 18S rDNA and 28S rDNA. Besides the phylogenetic analysis this paper also provides a detail description of the two new species and redescription of Eucypris cisternina based on the type material deposited at the Invertebrate Collection of the Smithsonian Museum in Washington.

\section{Material and Methods}

\subsection{Sampling methods and taxonomy}

Sampling campaigns were carried out in southern Mexico (Fig. 1) during 2011 and 2013. Lacustrine ecosystems were sampled with a hand net of $50 \mu \mathrm{m}$ mesh size. The net was thoroughly passed through the submerged vegetation on the littoral zone. When a limnetic zone was developed, several vertical tows with a plankton net (50 $\mu \mathrm{m}$ mesh size, $30 \mathrm{~cm}$ mouth) were taken. Samples from the Chetumal bay were collected using a net of $60 \mu \mathrm{m}$ mesh size at different points along the coast line by filtering at least 200 L of water. All samples were fixed with $96 \%$ ethanol and preserved in refrigeration until laboratory analysis. Ostracod specimens were extracted under a stereomicroscope Leica EZ4. Dissections of soft and hard part were carried out, in a mixture of distilled water and glycerin; dissected soft parts were mounted on microscope slides in Hidromatrix ${ }^{\circledR}$ mounting medium. Ostracod carapace photographs were taken with a 
Canon Powershot A640 digital camera attached to a Zeiss Axiostar-plus light microscope. Soft parts were examined and characterized with the aid of a camera lucida using the Leica DM 2500 compound microscope, equipped with NPlan objectives and a drawing tube attachment. Scanning Electron Micrographs (SEM) were taken with a Hitachi S-4700 scanning electron microscope at Eulji University (Seoul).

The terminology for the A1, Md, Mxl, L5 and L6 follows Broodbakker and Danielopol (1982), and for the L7 Meisch (1996). Here, the view of Meisch (2007) regarding the terminology and homology of the most posterior appendage on the ostracod body ("furca") is accepted. Setal classification system follows Garm (2004). Kempf's (1980a-d, 1991, 1997a-d) indexes and bibliographies of the freshwater ostracods have been extensively used in checking the availability of names and publications.

\subsection{DNA amplification}

In the first step of the DNA extraction specimens were kept for 2-3 hours in distilled water. LaboPass Tissue Mini extraction kit (Cosmo Genetech Co., LTD, Korea) was used in all further steps of extraction, following the manufacturer's protocol. Fragments of 28S rDNA were amplified using the primer pairs dd/ff, ee/mm, vv/xx from Hills and Dixon (1991), using a TaKaRa PCR Thermal Cycler Dice. PCR reactions were carried out in $25 \mu l$ volumes, containing: $5 \mu \mathrm{l}$ of the DNA template, $2.5 \mu \mathrm{l}$, 10x ExTaq Buffer, $0.25 \mu \mathrm{l}$ of TaKaRa Ex Taq (5 units/ $\mu \mathrm{l}), 2 \mu \mathrm{l}$ of dNDTP Mixture (2.5 mM each), $1 \mu$ l each primer, and $13.25 \mu$ l distilled $\mathrm{H}_{2} \mathrm{O}$. The PCR protocol consisted of initial denaturation for 5 minutes at $94^{\circ} \mathrm{C}, 40$ cycles of denaturation for $35 \mathrm{~s}$ at $95^{\circ} \mathrm{C}$, annealing for 1 minute at $50^{\circ} \mathrm{C}$, extension for 1 minute at $72^{\circ} \mathrm{C}$. Final extension was at $72^{\circ} \mathrm{C}$ for 5 minutes. Fragments of $18 \mathrm{~S}$ rDNA were amplified using the primers from Yamaguchi (2003). For the initial amplification the F1/R9 primer set was used, which amplifies around 1800 
base pair, if no band was apparent than internal primer pairs were used in the PCR reaction in which $1 \mu l$ of the PCR product was used as the template. Only in the case of Physocypria cf. biwaensis the primer pare from Kato et al. (1997) was used. The PCR reaction was the same as for 28S rDNA. PCR settings for the amplification of 18S rDNA followed Yamaguchi (2003) and Kato et al. (1997) for each corresponding primer pair. The PCR products were electrophoresed on $1 \%$ agarose gels, and, if DNA was present, the products were purified for sequencing reactions, using the LaboPass PCR Purification Kit following the guidelines provided with the kit. DNA was sequenced on ABI automatic capillary sequencer (Macrogene, Seoul, South Korea) using the same set of primers.

\subsection{Molecular data analysis}

All obtained sequences were visualized using Finch TV version 1.4.0

(http://www.geospiza.com/Products/finchtv.shtml). Each sequence was checked for the quality of signal and sites with possible low resolution, and corrected by comparing forward and reverse strands. BLAST (Altschul et al., 1990) searches revealed that the obtained sequences were ostracod in origin and not contaminants. Each of the three 18S rDNA gene regions, as well as 28S rDNA sequences were aligned in MEGA 6 (Tamura et al., 2013) with ClustalW (Thomson et al., 1994) using default parameters and then concatenated. MEGA was also used for calculation of p-distances (Table S1, S2). The following phylogenetic analyses were performed: Maximum Likelihood (ML) and Maximum Parsimony (MP) using PAUP 4.0a136 (Swofford, 2002) and the best-fitting evolutionary model. For the best-fitting evolutionary model, the program jModelTest 2.1.6 (Darriba et al., 2012; Guindon and Gascuel, 2003) was used with Akaike information criterion (Hurvich and Tsai, 1989). In the ML and MP analyses the bootstrap values (Felsenstein, 1985) were calculated with 1000 pseudo-replicates. Although the three fragments of $28 \mathrm{~S}$ rDNA 
were initially individually aligned, the analyses were performed on three fragments assembled in a single file. In both alignments the internal gaps were removed manually, and in 28S rDNA all sequences were trimmed to the same length, while in the $18 \mathrm{~S}$ rDNA alignment sequences were only trimmed at the 3 'end and not at 5'end (the 3' end was much more variable in terms of length). All sequences (in their original lengths) are deposited in the GenBank (Table S3).

3. Results

\subsection{Taxonomic Description}

Order Podocopida Sars, 1866

Suborder Cypridocopina Jones, 1901

Family Cyprididae Baird, 1845

Subfamily Cyprinotinae Bronstein, 1947

3.1.1 Genus Manuelcypris gen. nov.

\subsubsection{Type species}

Manuelcypris chetumalensis sp. nov.

\subsubsection{Other species}

M. antillensis (Broodbakker, 1982) comb. nov., M. cisternina (Furtos, 1936) comb. nov., $M$. punctata (Keyser, 1975) comb. nov., and Manuelcypris tabascena sp. nov.

\subsubsection{Diagnosis}

Carapace stout between 0.5 and $1 \mathrm{~mm}$ long. In lateral view reniform with relatively low dorsal margin. Surface of the carapace smooth to poorly ornamented. RV sometimes with developed marginal tubercles. Selvage on both valves peripheral. Inner list only anteriorly present. Marginal pore canals relatively short and straight. A1-7segmented, with small Rome's and Wouters organs; A2 sexually dimorphic with respect of terminal claws and setal elongation. A2 swimming setae at least reaching the tip of the claws. Maxillular palp with cylindrical terminal segment. L5 
without "c" setae, but with "b" and "d" setae present. Setae "a" and "a" sometimes missing as well. Prehensile palps asymmetrical with left palp being smaller than the right one. L6 5segmented, without basal setae. L7 typical for the family. UR with both claws and both setae well-developed, the latter being long. Hemipenis with two shields: lateral and medial.

\subsubsection{Etymology}

The genus is named in honor of Dr. Manuel Elias-Gutierrez from "El Colegio de la Frontera Sur (ECOSUR)" (Chetumal, Mexico) for his continuous support and effort in the molecular studies of speciation in diverse crustacean taxa from the Neotropical region.

3.1.2. Manuelcypris chetumalensis sp. nov. (Fig. 2, Fig. 3, Fig. 4, Fig. 5, Fig. 6, Fig. 7 and Fig. 8)

\subsubsection{Type material}

Holotype: adult male dissected on one slide (ECO-CH-Z-09334), Allotype: adult female dissected on one slide (ECO-CH-Z-09335), Paratype: one adult male and one adult female dissected one slide each, approximately 15 specimens preserved in $99 \%$ ethanol, deposited at the National Institute of Biological Research, Seoul (NIBR....).

\subsubsection{Type locality}

Near mouth of rain water sewer, Chetumal bay, Chetumal, Quintana Roo, México, $18^{\circ} 31^{\text {' }}$ 40.65 ”N, 88 15' 57.52”W (Fig. 1a).

\subsubsection{Etymology}

The species is named after Chetumal Bay (Mexico), from where it was collected.

\subsubsection{Diagnosis}

Carapace relatively small, not exceeding $1 \mathrm{~mm}$ in length. Dorsal margin of carapace slightly arched. Greatest height around middle but slightly toward anterior end. Anterior margins with abundant setaesetae. Valves without marginal tubercles. A2 swimming setae by far exceeding 
tips of terminal claws. L5 with "b" and "d" setae present. L6 with basal segment bare and with eseta just reaching the distal end of the following segment. UR almost straight in female but strongly arched in male. Anterior claw reaching the middle of the ramus. Genital field round with one projection. Hemipenis with a-lobe slightly shorter than b-lobe.

\subsubsection{Description of male}

Carapace in lateral view elongated (Fig. 2A and Fig. 5A, B). Valves asymmetrical, LV overlapping RV anteriorly, posteriorly and ventrally (Fig. 4E, F). Carapace with dorsal margin slightly arched. Greatest height around middle, slightly toward anterior end. Anterior and posterior margins broadly rounded, anterior margin slightly narrower than posterior one. Ventral margin fairly covered by setaesetae and slightly concave around middle. Calcified inner lamella shorter posteriorly than anteriorly. Anteriorly equaling $8.2 \%$ and posteriorly $6.1 \%$ of total length of the carapace. Marginal pore canals straight, setae more abundant anteriorly than posteriorly. Muscle scars imprints consisting of five grouped scars (Fig. 2A). Inner list well-developed anteriorly (Fig. 2B, C). Surface of carapace smooth, except anteriorly where small pits are present (Fig. 4F). Relatively prominent warts present on RV anteriorly (Fig. 4F), on the LV warts very small. Surface sensilla exiting from rimmed pores. No marginal tubercles present on either of valves. Length of valves (holotype): $L V=500 \mu \mathrm{m}, \mathrm{RV}=483 \mu \mathrm{m}$.

A1 (Fig. 5C ). 7-segmented. First segment anteriorly with one smooth seta that just reaches the distal end of the segment. Postero-distally, two unequally long serrulate setae. Longer one reaching the distal end of penultimate segment while shorter one just exceeding the distal end of fifth segment. Second segment with one antero-apical smooth seta that exceeds the middle of following segment. Rome's organ not observed. Third segment is carrying apically one anterior and one posterior seta. Anterior one just reaches the distal end of fifth segment. Posterior seta is serrulate and it exceeds the middle of following segment. Fourth segment with two long and bare 
setae antero-distally; postero-distally on this same segment, two unequally long setae, longer one bare and almost reaching the middle of terminal segment. Fifth segment antero-distally with two long and bare setae; postero-distally with two unequally long setae, both by far exceeding distal end of terminal segment. Sixth segment with five bare setae. The four most anteriorly located are long while the most posterior seta is short. Terminal segment is carrying two long and one short setae in addition to the aesthetasc $y a$, which is 1.8 times longer than terminal segment. Length ratios of last five segment 1.8: 1.2: 1: 0.8: 1 .

A2 (Fig. 6A) 5-segmented. Coxa is carrying medially one long and smooth seta that exceeds the distal end of the coxa. Postero-distally on the same segment, two unequally long serrulate setae not reaching the middle of following segment. Basis postero-apically with one long and serrulate seta that just exceeds the middle of penultimate segment. Exopod consists in a plate with three unequally long setae. Longer one is serrulate and just exceeds the distal end of following segment. The two most posterior setae are smooth and short not reaching the middle of following segment. First endopodal segment hirsute with aesthetasc Y relatively long, 1.5 times longer than terminal segment. Postero-distally on the same segment one serrulate seta is exceeding the distal end of terminal segment. Natatory setae are not equally long. The five most posteriorly located are smooth and long, exceeding the tips of the claws. Most anterior seta short, reaching the middle of following segment. Second endopodal segment with t-setae (t1-t4) unequally long. Antero-medially two smooth and unequally long setae. Seta z2 elongated but not reaching the tips of terminal claws; seta z1 claw-like two times as long as terminal segment. Claws G1 and G2 subequally long, 5.2 times longer than terminal segment, both distally strongly serrate. Claw G3 slightly smaller than adjacent claws, five times longer than terminal segment, distally strongly serrated as well. Terminal segment carrying two smooth and equally long setae. Aesthetasc ya 
slender, 1.2 times longer than terminal segment. Gm claw strong and elongated with 5.1 times the length of terminal segment. GM claw seta-like.

Md. (Fig. 5F) Palp 4-segmented. First segment with one long and smooth seta that exceeds by far the distal end of terminal segment. Setae S1 and S2, thick and pappose, $\alpha$-seta slender, smooth and relatively long, reaching the middle of following segment. Respiratory plate with six smooth rays. Second segment dorso-distally with three unequally long setae, longer ones reaching the distal end of terminal segment while shorter one just exceeds the middle of following segment. Ventro-distally of this same segment, four approximately equally long setae are present, the most ventral ones pappose while the most dorsal one bare. Third segment hirsute with a row of long setae medially. Dorso-distally with a bunch of four smooth and long setae, all of them overpassing by far the distal end of terminal segment. Apically on this segment four unequally long setae. $\gamma$-seta pappose and twice as long as terminal segment. Fourth segment (terminal segment) almost equally long as wide and carrying two bare and two pappose setae. Mxl. Palp 2-segmented. First segment elongated and carrying six apical setae. Two of them serrulate while the other four smooth. Terminal segment 1.3 times longer than wide and carrying three long claw-like setae and three slender and smooth setae. Third endite with nine apical setae, three of them serrulate while the other six smooth. Teeth bristles strongly serrated distally. Second and first endite with eight and eleven smooth setae respectively. Branchial plate (Fig. 5D) with fifthteen long and pappose rays followed by two small and smooth setae.

L5. Protopodite apically with twelve setae, three of them smooth and the others serrulate. Seta bsmooth and d-seta serrulate. Exopodite consisting in a plate with six rays. Palps asymmetrical and two segmented. First segment of right palp with three outgrowths forming small projections; terminal finger stout and strongly sclerified (Fig. 6E). Left palp carrying on first segment two 
small projections; terminal finger strongly curved (Fig. 6B). Fingers on both palps terminating in a nipple-like seta.

L6. 5-segmented. Basal segment bare. First endopodal segment slightly hirsute and with a relatively short and serrulate e-seta that not reaches the distal end of following segment. Second endopodal segment with f-seta serrulate and short, just reaching distal end of following segment. Third endopodal segment with g-seta short and serrulate. Terminal segment carrying h1 and h3 setae short and smooth. Terminal claw (h2-setae) equaling 1.3 times the length of last three segment combined.

L7 (Fig. 6C). 4-segmented. Basal segment with d1, d2 and d3 setae long and serrulate. Seta "e" exceeding the middle of following segment. Seta f- serrulate and just reaching distal end of the segment that carries it. Terminal segment with h1-seta missing, h2-seta claw-like and distally hairy and h3-seta serrulated and elongated.

UR (Fig. 5E). Ramus curved and postero-distally slightly hirsute. Anterior claw distally serrate and reaching the middle of the ramus. Anterior seta short and smooth, reaching one third of the anterior claw. Posterior claw curved and distally serrated, equaling one third of the length of the ramus. Posterior setae smooth, and slightly smaller than posterior claw. Length ratios between ramus, anterior and posterior claws equaling 2.8: 1.4: 1 .

Hemipenis (Fig. 6D) with the a-lobe and b-lobe well developed. Lobe a, triangular shaped. Lobe $\mathrm{b}$ foot-like and slightly larger than a-lobe. Internal ducts only once coiled. Ejaculatory process simple.

\subsubsection{Description of female}

Carapace similar to male but slightly smaller. In lateral view elongated (Fig. 7A, B). Calcified inner lamella differing in length with male. Anteriorly equaling $11.2 \%$ and posteriorly $3.2 \%$ of total length of the carapace. Muscle scars imprints as in males consisting in five grouped scars 
(Fig. 7A, B), most posterior ones, elongated. Surface of carapace and valve overlap same as in male (Fig. 4A-D) smooth. Carapace size: $L V=487.5 \mu \mathrm{m}$ and $\mathrm{RV}=475 \mu \mathrm{m}$.

A1 (Fig. 7E). Similar as in male with exception of some of the posterior setae (on the third and fourth segments) that are smooth instead of serrulate as in male. Third segment is carrying two antero-distally setae, at difference of male that is carrying one seta in the same segment. Rome's organ was not observed.

A2 (Fig. 7D). 5- segmented. Setae from coxa and basis are smooth at difference of males in which all setae are serrulate. t-seta (1-4) shorter than in male. All z-seta present, being slender and smooth. Seta z1, longer than the other z-setae. Postero-distally on penultimate segment there is one small short seta, that is absent in male. G1 and G3 claw subequally long, 5.6 times longer than terminal segment. G2 claw reduced, 4.8 times longer than terminal segment. Third endopodal segment (terminal segment) with GM seta resches beyong the tips of G1 and G3. Gm claw, slender and equaling 2.8 times the length of terminal segment. Aesthetasc ya short and accompanied by two setae, longer one smooth, while shorter one serrulate. Md (Fig. 7C), Mxl (Fig. 8A) as in male.

L5 (Fig. 7F, G). Endopodite with three apical setae, longer one serrulate and shorther ones smooth. Exopodite consisting in a plate with six rays. Protopodite with b-seta smooth and d-seta serrulate. Apically with twelve setae serrulate, except three of them which are smooth. L6 (Fig. 8C) and L7 (Fig. 8B) as in male.

UR and genital process (Fig. 8D, E). Ramus (Fig. 8E) postero-distally slightly hirsute and straighter than in male. Anterior claw is slightly curved reaching one half of the length of the ramus. Posterior claw with tip curved and reaching slightly more than one third of the length of the ramus. Anterior seta smooth not reaching the middle of anterior claw. Posterior seta serrulate and slightly smaller than posterior claw. Length ratios between ramus, anterior and posterior 
claws are as follows: 2.5:1.4: 1. Genital field (Fig. 8D) mostly rounded but with one projection carrying sensorial organs.

\subsubsection{Remarks}

Manuelcypris chetumalensis and M. cisternina are the only two species in the genus without any marginal tubercles. Manuelcypris cisternina, unlike M. chetumalensis have neither of the two "a" setae on the L5, and has less elongated carapace in the lateral view. Manuelcypris chetumalensis differs from $M$. tabascena also by other carapace characteristics, such as more steeply inclined dorsal margin. Of the soft parts, the most prominent difference is the number of swimming setae on A2 ( $\operatorname{six}$ in $M$. chetumalensis and five in $M$. tabascena), in addition to the fine differences in the lengths of the L6 and L7 setae, and length ratio between anterior and posterior claw on the UR. Manuelcypris chetumalensis is also almost two times smaller than M. tabascena. Manuelcypris chetumalensis has similar hemipenis and prehensile pals like both M. antillensis and M. punctata with a little less pronounced "heel" part of the outer lobe on the hemipenis and less convex distal margin of the same part. In addition, the new species differs form $M$. antillensis in a considerately longer posterior seta on the UR, and longer setae on the L6, and from $M$. punctata in the absence of pits on the surface of the carapace.

\subsubsection{Manuelcypris tabascena sp. nov. (Fig. 9, Fig. 10, Fig. 11, Fig. 12 and Fig. 13)}

\subsubsection{Type material}

Holotype: adult female dissected on one slide (ECO-CH-Z-07708). Paratype: adult female dissected on one slide from Acayucan-Cosamaloapan wetlands (ECO-CH-Z-07709). Other material: 17 specimens from type locality, all females preserved in 70\% ethanol (ECO-CH-Z09333).

\subsubsection{Type locality}


Lake Vernet, Tabasco Mexico $17^{\circ} 52^{\prime} 22.8^{\prime}$ 'N, 92 32 '45.1' 'W. Other localities Miguel Hidalgo

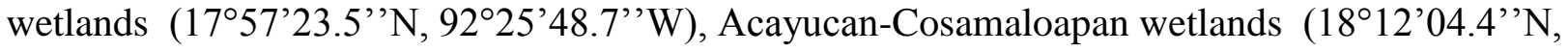

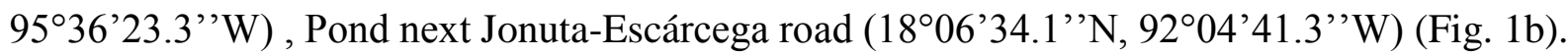

\subsubsection{Etymology}

The name is after the Tabasco, Mexican state, where this species is mainly distributed.

\subsubsection{Diagnosis}

Medium size organisms, almost reaching $1 \mathrm{~mm}$ in length. Carapace with dorsal margin slightly arched. Greatest height located slightly around the middle but slightly toward posterior end. Right valve with marginal tubercles ventro-anteriorly and posteriorly. Five swimming setae on A2, longer ones exceeding the tips of distal claws. L5 with b- and d- setae . Basal segment on L6 bare and e-seta exceeding the distal end of following segment. UR straight with anterior claw reaching the half length of the ramus. Genital field round.

\subsubsection{Description of female}

Carapace in lateral view elongated (Fig. 9A, Fig. 11 and Fig. 12 A, B). LV slightly larger than RV. Carapace in dorsal margin slightly arched, greatest height around middle but slightly toward posterior end (Fig. 9B, D). Greatest height equaling 57\% of total length of carapace. Carapace with anterior and posterior margins broadly rounded, anterior margin narrower than posterior one. Ventral margin covered by sparsely setae and slightly concave around mid-lenght. Right valve in antero and postero-ventral margins with small tubercles (Fig. 10 and Fig. 11). Left valve anteriorly with very small wart-like structures (Fig. 9C). Calcified inner lamella narrow, anteriorly equaling $9 \%$ and anteriorly $3.6 \%$ of total length of carapace. Marginal pore canals straight and denser anteriorly than posteriorly. Selvage peripheral. Muscle scars consisting on four compact scars and two elongated scars more antero-ventrally (Fig. 9F). Surface of carapace 
smooth, to finely pitted (Fig. 9E, Fig. 11 and Fig. 12A, B). Surface sensilla exiting from rimed pores (Fig. 9E). Length of $L V=971 \mu \mathrm{m}$, length of $\mathrm{RV}=942 \mu \mathrm{m}$.

A1 (Fig. 13A) 7-segmented. First segment is carrying postero-distally two unequal serrulate setae, longer one is reaching the middle of the sixth segment while shorter one is just reaching the distal end of the fourth segment. Antero-medially on the same segment one serrulate and short seta is just reaching the distal end of the segment. Wouter's organ small, located proximally on the segment. Second segment, postero-medially with the Rome's organ short. Antero-distally a serrulate seta is just overpassing the distal end of following segment. Third segment is carrying two apical setae. The most anterior one is serrulate and reaching the distal end of fifth segment, while the most posterior seta is serrulate and short, not reaching the distal end of following segment. Fourth segment posteriorly with one serrulate seta that exceeds the distal end of penultimate segment; anteriorly two subequally long and hairy setae, 7.1 times longer than terminal segment. Fifth segment with two postero-distal serrulate setae, both by far exceeding the distal end of terminal segment. Antero-distally with two hairy and equally long setae, 11.2 times longer than terminal segment. Sixth segment hirsute distally and carrying five apical setae. Four of them hairy and subequally long, 13.5 times longer than terminal segment. Shorter seta is serrulate and 1.2 times longer than terminal segment. Seventh segment (terminal segment) hirsute distally and bearing two long and hairy setae, 11.6 times longer than the segment; one short and serrulate seta, 3.8 times longer than terminal segment and the aesthetasc ya, which is about equally long than the terminal segment. Length ratios of last five segments are as follows

\section{4:1.1:0.9:1.}

A2 (Fig. 12E). 5- segmented. Coxa is carrying two postero-distally short and serrulate setae, longer one just reaching the middle of following segment while shorter one reaches one third of next segment. Basis with one long and serrulate seta reaching the middle of the penultimate 
segment. Exopod is reduced to a plate with three unequally long setae. Longer one serrulate and exceeding the distal end of the following segment. Medial seta is smooth and reaching one third of the following segment. Most posterior seta is very small. First endopodal segment hirsute with aesthetasc Y, 1.3 times longer than terminal segment. Postero-distally on this same segment a slender and serrulate seta is just exceeding the distal end of the following segment. Five natatory setae are located antero-distally on this segment, four of them are slightly setulae and equally long, overpassing the tips of the terminal claws. Shorter seta is serrulate and just exceeding the middle of the penultimate segment. Second endopodal segment hirsute with all t-setae present. Seta $\mathrm{t} 1$ just reaching the proximal end of the terminal segment, while all other t-setae exceeding the distal end of terminal segment. Antero-medially on this segment two smooth setae are overpassing the distal end of terminal segment. Setae z1 and z2 are slender and subequally long, exceeding the tips of terminal claws. Seta $\mathrm{z} 3$ short, 3.3 times the length of terminal segment. Claws G1 and G3 subequally long, five times the length of terminal segment. Claw G2, slightly smaller than adjacent claws, 4.2 times the length of terminal segment. Third endopodal segment (terminal segment) with GM claw long and distally serrulate, four times the length of terminal segment. Gm claw short, two times as long as terminal segment. Two accompanying setae are present as well on this segment, longer one smooth while shorter one serrulate. Aesthetasc ya, slender and slightly smaller than terminal segment.

Md (Fig. 12C). Palp 4-segmented (Fig. 12D). First segment ventrally with four setae. The most proximal one is long and serrulate. Setae S1 and S2 pappose and subequally long, overpassing the distal end of terminal segment. $\alpha$-seta slender and short, just exceeding the distal end of the following segment. Second segment dorso-distally with three unequal serrulate setae. Longer ones exceeding the distal end of terminal segment while shorter one not reaches the distal end of following segment. Ventro-distally of this same segment with four pappose and equally long 
setae, five times the length of terminal segment. $\beta$-seta small and pappose, just exceeding the middle of following segment. Third segment hirsute with a row of setae medially. This segment is carrying dorso-distally four unequal setae, the most external one serrulate, while the other three smooth. Antero-apically on this segment with four dissimilarly long setae, all of them pappose and by far exceeding the distal end of terminal segment. $\gamma$-seta is strongly pappose and elongated, by far overpassing the distal end of last segment. Fourth segment (terminal segment) hirsute, with 1.2 times longer than wide. This segment is carrying distally six setae, all of them serrulate but unequally long. Longer seta with 2.6 times the length of the segment.

Mxl. Palp 2-segmented (Fig. 12F). First segment hirsute and distally with four long serrulate setae and three pappose setae. Second segment hirsute with three claw-like setae subequally long, 1.2 times longer than terminal segment and other three smooth and slender setae. Third endite of maxilla with two large bristles apically strongly serrated (Fig. 12G).

L5 (Fig. 13B). Protopodite apically with twelve unequally long serrulate or plumose setae. Setae b- and d- hairy and long. Endopodite with three apical setae unequally long and pappose. Exopodite consisting of a plate and six pappose rays.

L6 (Fig. 13D). 5-segmented. Basal segment bare. First endopodal segments hirsute with e-seta serrulate and long, exceeding the distal end of the following segment. Second endopodal segment with f-seta serrulate and just reaching the distal end of following segment. Third endopodal segment apically with g-seta short and serrulate and one additional seta smaller and serrulate. Terminal segment carrying a strong claw (h2 seta), distally curved and serrated. Setae h1 and h2 slender and serrulate.

L7 (Fig. 13C). Basal segment with d1, d2 and dp setae long and serrulate. Second segment with e-seta serrulate and long, overpassing the half length of following segment. Third segment with f- 
seta serrulate and short, just reaching the distal end of the segment. Terminal segment with h1seta small and hook-like, h2-seta claw-like and distally serrulated, h3-seta long and serrulate. UR and genital process (Fig. 13E). Ramus slender and hairy along posterior margin. Terminal claws slightly curved and distally serrulated. Anterior claw equaling one half of the length of ramus. Anterior seta serrulate and not reaching the half length of anterior claw. Posterior claw slightly serrulate and reaching two fifths of the length of the ramus. Posterior seta serrulate and exceeding the half length of posterior claw. Length ratios between ramus, anterior and posterior claws equaling 2.6: 1.2: 1. UR attachment distally bifurcated (Fig. 13F). Genital process rounded.

\subsubsection{Remarks}

Manuelcypris tabascena, possess marginal tubercles along the RV and because of this, it is more similar to M. antillensis and M. punctata than to the other two species. However, unlike, $M$. antillensis, this new species has neither of the "a" setae on the L5 what places it closer to $M$. punctata and M. chetumalensis. Manuelcypris tabascena also has only five swimming setae on the A2 and, unlike M. punctata does not have prominent pits on the surface. Additional difference from M. antillensis is a much longer posterior seta on the UR.

3.1.4. Manuelcypris cisternina (Furtos, 1936) comb. nov. (Fig. 14, Fig. 15, Fig. 16 and Fig. 17)

\subsubsection{Synonymy}

Eucypris cisternina n. sp. - Furtos (1936), p. 107, Figs. 124-127.

\subsubsection{Material examined}

Holotype, adult female, SM - 67971. Champotón, Campeche, Yucatán península, México, $19^{\circ} 21^{\prime} \mathrm{N},-90^{\circ} 43^{\prime} \mathrm{W}$.

\subsubsection{Diagnosis}


Relatively small organisms, less than $1 \mathrm{~mm}$ in length. Carapace elongated with dorsal margin slightly arched. Greatest height located in the middle. Surface of carapace smooth. Ventral margin straight but little convex at mouth region. Swimming setae of A2 slightly overpassing the tip of claws. L5 with small and bare a-setae, serrulate b-seta and pappose d-seta. L6 with basal segment bare and e-seta relatively short, not reaching the distal end of following segment. UR straight with anterior claw not reaching the middle of ramus.

\subsubsection{Redescription of female}

Carapace in lateral view elongated (Fig. 14 and 15A, B). LV slightly larger than RV. Carapace in dorsal margin slightly arched, greatest high located around middle and equaling $50 \%$ of total length of the carapace. Anterior and posterior margins broadly rounded and covered by sparsely setae. Posterior margin slightly narrower than anterior one. Ventral margin almost straight, except in the mouth region where it is slightly convex (Fig. 14). Calcified inner lamella is equaling $6.3 \%$ anteriorly and $3.2 \%$ posteriorly of the total length of carapace. Marginal pore canals straight and denser anteriorly than posteriorly. Muscle scars imprints consisting of four small and compact scars medially and two slightly elongated scars located more antero-ventrally. No marginal tubercles present. Surface of carapace smooth. Length of $L V=650 \mu \mathrm{m}$. Length of RV=620 $\mu \mathrm{m}$. A1 (Fig. 16A). 7-segmented. First segment antero-medially with one bare seta just exceeding the distal end of the segment. Postero-distally with two setae that differ in length and appearance. Longer one is serrulate and almost reaching the end of penultimate segment; shorter seta is smooth and reaches the middle of fourth segment. Second segment with an antero-apical bare seta that not exceeds the middle of following segment. Rome's organ not observed. Third segment antero-distally with one seta that reaches the middle of sixth segment. Postero-apically on this same segment one slender seta not reaches the end of the following segment. Fourth segment with two long bear setae antero-distally. Postero-distally, two apical bare setae are 
unequally long. Longer one is almost reaching distal end of penultimate segment while shorter one is just exceeding the end of the following segment. Fifth segment carries anterior-distally two long bare setae and postero-distally two unequal setae, the last by far exceeding the distal end of last segment. Sixth segment is bearing two unequally long and bare setae postero-distally and two long setae medially. Terminal segment with two long and one relatively short setae; the last is at least three times longer than terminal segment. Aesthetasc ya missing. Length ratios of last five segments are as follows: 2.1:1.5:1.2:1:1.

A2 (Fig. 15E) 5-segmented. Coxa with two subequally long smooth setae; shorter one exceeding the distal end of the segment, while longer one is reaching the middle of following segment. Basis is carrying one long serrulate seta postero-distally, that exceeds the distal end of third segment. Exopod is consisting of a plate with three unequal setae. Longer seta is serrulate and reaching three fourths of following segment, middle seta is small, reaching one seventh of following segment and most anterior seta is very small. First endopodal segment with aesthetasc Y, elongated and equaling 1.4 times the length of terminal segment; Postero-distally on the same segment there is one long serrulate seta, which not reaches the distal end of the following segment. Swimming setae are unequally long, five of them are smooth and extended slightly beyond tip of terminal claws, while the most anterior setae is short and it just exceeds the middle of following segment. Second endopodal segment with t-setae (t1-t4 setae) smooth and unequally long, but all of them exceeding the middle of terminal segment. Antero-medially on the same segment two unequally long smooth setae. Postero-distally a small serrulate setae is present, not reaching the distal end of terminal segment. Setae z2 and z3 are slender and almost equally long, with 2.4 times longer than terminal segment. Seta $\mathrm{z} 1$ is slender with more than five times the length of terminal segment. Claws G1 and G3 subequally long, five times the length of terminal segment. G2 claw is reduced, being 2.6 times as long as the terminal segment. Third endopodal 
segment (terminal segment) short, with the GM claw slightly smaller than G1 and G3 claws. Gm claw is seta-like, with 2.1 times longer than terminal segment. All terminal claws strongly serrulated distally. Two additional small and smooth setae are present on the terminal segment, both are equally1.2 times the length of terminal segment.

Md. (Fig. 16B). Palp 4-segmented (Fig. 16C). First segment ventrally with S1 and S2 setae pappose and extended to almost the end of terminal segment. $\alpha$-seta was not observed. Dorsally on this same segment the respiratory plate is carrying four plumose setae. Second segment dorsally with three unequally long setae; longer ones smooth and almost reaching the distal end of last segment. Ventrally on this same segment, four slender and pappose setae are equally long, exceeding the distal end of terminal segment. $\beta$-seta is thick at the base and pappose. Third segment is carrying dorso-distally four bare setae, all of them are exceeding the distal end of terminal segment. Ventro-distally two unequal setae are present; longer one is serrulate and it is by far exceeding the distal end of terminal segment; shorter seta is smooth and do not reach the middle of terminal segment. $\gamma$-seta, swollen and strongly pappose, it just exceed the distal end of terminal segment. Fourth segment (terminal segment) is carrying four elongated claw-like setae and two short and thin setae. Terminal segment is 1.3 times longer than wide.

Mxl. Respiratory plate (Fig. 15C) is carrying eleven short and papposse setae proximally, followed by eight long and pappose setae. Two additionally short and serrulate setae are present distally.

L5 (Fig. 17C) Palp with three unequally long setae, all of them distally slightly serrulate. Exopod consist in a plate with five rays, all of them smooth. Protopod with two short and smooth a-setae, a serrulate b-seta and a pappose d-seta. Protopod apically with fourtheen almost equally long pappose or serrulate setae. 
L6 (Fig. 17A) 5-segmented. Basal segment bare. First endopodal segment slightly hirsute, with e-seta serrulate and short, not reaching the distal end of following segment. Second endopodal segment with f-seta serrulate and just exceeding the distal end of penultimate segment. Third endopodal segment slightly hirsute and with g-seta serrulate and exceeding the distal end of terminal segment. A very small seta is located adjacent to g-seta. Terminal segment small and carrying a slender h1-seta, which is slightly serrulate and two times longer than terminal segment; h3-seta serrulate, 1.6 times as long as terminal segment and a strong claw (h2 seta) distally strongly serrulate, 5.7 times longer than terminal segment.

L7 (Fig. 17B) 4-segmented, Basal segment carrying the d1, d2 and dp setae. All of them serrulate. Second segment with e-seta serrulate and exceeding the middle of following segment. Seta $\mathrm{f}$ - is serrulate and just reaching the distal end of the segment that carries it. Seta g- missing. Penultimate and terminal segment not clearly divided. Terminal segment oblong with h1-seta short and hook-like; h2-seta claw-like and slightly curved distally; h3-seta long, more than 2.5 times longer than h2-seta.

UR (Fig. 15D) Ramus slender and carrying anteriorly a claw that almost reaches the middle of the ramus. Anterior seta slender and not reaching the middle of anterior claw. Posterior claw slightly exceeding one third of the length of the ramus. Posterior seta exceeding the middle of the length of posterior claw. Terminal claws slightly curved and fairly serrulate distally. Length ratios between ramus, anterior and posterior claws equaling $4.1: 1.2: 1$.

\subsubsection{Remarks}

Manuelcypris cisternina seems to be most closely related to M. antillensis. They both have relatively elongated carapace in comparison to the other three species, both have "a" setae on the L5 and also carry a peculiar, additional seta on the L5. The postero-dorsal margin in $M$. antillensis is a bit more angular than in M. cisternina, and the RV carries marginal tubercles, 
which are absent in M. cisternina. Additionally, M. antillensis has a shorter posterior seta on the UR.

3.2. Key to species of the genus Manuelcypris

1. Setae "a" and "a" "present on L5 ... 2

- Setae "a" and "a" absent on L5 ... 3

2. Posterior seta on UR not reaching $1 / 3$ of the $\mathrm{L}$ of the posterior claw, marginal tubercles present on the RV ... M. antillensis (Broodbakker, 1982) comb. nov.

- Posterior seta on the UR reaching $1 / 2$ of the $L$ of the posterior claw, marginal tubercles absent on the RV ... M. cisternina (Furtos, 1936) comb. nov.

3. Marginal tubercles present along the RV ... 4

- Marginal tubercles absent along the RV ... M. chetumalensis n. sp.

4. Surface covered with prominent pits ... M. punctata (Keyser, 1975)

- Surface almost smooth ... M. tabascena $\mathrm{n} . \mathrm{sp}$.

\subsection{Molecular analysis}

The total length of the $18 \mathrm{~S}$ rDNA alignment was 1660 , while that of $28 \mathrm{~S}$ rDNA was 1561 base pairs long. Table 1 summarizes the results of the analysis on both alignments. Based on Akaike information criterion (Hurvich and Tsai, 1989) evolutionary best fit model for the 18S rDNA alignment was TIM2+I+G (transition model) and for 28S rDNA it was GTR+I+G (Rodríguez et al., 1990). The trees obtained from both ML and MP methods (Fig. 18 and Fig. 19) on both alignments were rooted with three sequences belonging to Cyclocypridinae: Cypria exsculpta, Physocypria nipponica, and $P$. cf. biwaensis. The first two were downloaded from the GenBank while the last was obtained in this study (Table S4). Only the ML analysis of both genes has a 
high bootstrap support (100) for the ingroup taxa. On all obtained trees the support for the new genus, Manuelcypris, is very high (99 or 100), while the support for it and its closely related genera (Heterocypris, Cyprinotus, and Eucypris) ranged from 96/97 (of the 18S rDNA) and 72 and only 29 for the $28 \mathrm{~S}$ rDNA. The lowest support for this group was obtained by the ML analysis (Fig. 19B). In order to check if the GenBank sequence of Dolerocypris ikeyai caused such a low support for the group, this sequence was removed and the new alignment was analyzed again, but the obtained trees did not change the topology or the support significantly. We have also tried to see if the removal of the GenBank sequences belonging to Heterocypris vandouwei would change the topology of the genus Heterocypris on the $18 \mathrm{~S}$ rDNA tree (Fig. 18A, B) or the support for it, but this also did alter neither topology nor support. Heterocypris, in fact appears polyphyletic on all obtained trees. Other groups that received a high bootstrap support were Bradlecypris/Tanicypris and Chrissia/Stenocypris. The group containing Eucypris/Cyprinotus was strongly (100/99) supported only on the 28S rDNA trees.

\section{Discussion}

Manuelcypris has an isolated position within Cyprinotinae, and it shares several characters with Eucypridinae. For example, the carapace shape is more Eucypridinae than Cyprinotinae like, what probably prompted Furtos (1936) to place $M$. cisternina into the genus Eucypris. However, even though the frontal parts of the valves, at least in the type species (M. chetumalensis), carries prominent pores, those are not the same as the pores usually found in Eucypridinae ("porenwarzen"). Also, the other two Manuelcypris species do not have any peculiar frontal pores. It has to be pointed out that even within Eucypridinae the "porenwartzen" are not always present (such as, for example, in Eucypris pigra). Another reason why Manuelcypris was not 
include in Eucypridinae is the absence of "c" seta on the L5 in all three species and a longer posterior seta on the UR in comparison to most of the Eucypridinae species described so far. Cyprinotinae at the moment, beside the new genus, includes five additional Recent genera: Cyprinotus, Hemicypris Sars, 1903, Heterocypris, Homocypris Sars, 1924, and Riocypris Klie, 1935. Manuelcypris differs from all of them by the absence of any seta on the walking leg, and three out of five species also do not possess "a" setae on the L5. While representatives of Homocypris and Riocypris do not have any tubercles along the valve margins, tubercles are present along the LV margin in Hemicypris and right valve margin in Cyprinotus and Heterocypris. Taxonomic importance of the marginal tubercles on the valves has to be taken with caution when Cyprinotinae is in question because in Manuelcypris three species have them, while on the other two are absent. In addition, variability in the marginal tubercles has also been reported for Heterocypris incongruens (see Meisch, 2000). On the other hand, the chaetotaxy of the walking leg seems to be taxonomically very important in various Cypridoidea ostracod groups (see genera diagnoses in Karanovic, 2012). In Eucypridinae even the length ratio between two setae (d1 and d2) is important on the genus level (see Martens, 1989; Martens et al., 1992), while, only Candelocypris Baltanás, 2001 from Eucypridinae lacks any seta on the basal segments of L6 (see Baltanás, 2001).

All our phylogenetic analysis and both genetic markers strongly support an isolated position of Manuelcypris within Cyprinotinae (see Fig. 18 and Fig. 19). This is in congruence with the results of Kong et al. (2014) who only had the $18 \mathrm{~S}$ rDNA sequences of $M$. chetumalensis ("New Genus Mexico" on their phylogenetic tree). It has to be pointed out that this latter analysis, same as the present ones, includes only two representatives of Eucypridinae: Eucypris pigra and Eucypris sp. which always cluster with Cyprinotus sp. sequence. Such topology may question the validity of Eucypridinae, but since E. pigra is indeed a morphologically unusual representative of 
Eucypridinae such results only point out the importance of further studies. Another important result of our phylogenetic analysis is also the fact that Heterocypris does not appear monophyletic. With the exception of $H$. vandouwei, the sequence of which was downloaded from the GenBank, other Heterocypris sequences have been obtained for the purpose of this study and the study of Kong et al. (2014) and the animals were morphologically identified by one of us (I.K). Our initial identification was $H$. incongruens so the results of our analysis comes as a surprise, since we use very conservative, slowly evolving genes and still Heterocypris appears as a polyphyletic taxon (i.e. H. sp. $318 \mathrm{~S}$ sequence clusters with $H$. vandouwei, see Fig. 18). Although the bootstrap support for this group is low, it clearly indicates that Heterocypris incongruens may represent a species complex which needs further study. While Homocypris comprises only one species, restricted to South Africa (Sars, 1924), and the new genus is at the moment restricted to the northern Neotropics other genera have a wider geographic distribution. Cyprinotus has been recorded from North and Central America, Middle East, East Asia and Indo Pacific Region, but most of the species reported from the Americas have a doubtful position in the genus (see Karanovic, 2012). Hemicypris has been recorded mostly from the Southern Hemisphere, but, like in Cyprinotus, many species will undergo systematic changes in the future. Heterocypris has a global distribution and Riocypris has been recorded so far from Australia and South America (Díaz and Martens, 2014; Karanovic, 2008). The results of our study clearly indicate that the use of slowly evolving genetic markers can be very helpful in establishing new genera, even with limited number of taxa. It also shows that the Cyprididae is in need of a revision which should to include extensive use of various genetic markers, because the level of morphological taxonomy, although much higher than a couple of decades ago, still leaves the position of different taxa unresolved. Finally, our study also points 
out that Heterocypris incongruens may represent a complex of species, which has already been postulated by Rossi et al. (1990, 2007).

\section{Acknowledgments}

We would like to thank Mr T. Chad Walter (Smithsonian National Musuem of Natural History) for sending us Eucypris cisternina type material on loan. Financial support was provided by the National Institute of Biological Resources (NIBR) of Ministry of Environment, Korea (1834302). CONACYT (Mexico) provided fellowship $(218604,218639)$ to the second and third

authors. Comisión Nacional de áreas protegidas (CONAP) provided the collect permits. Special thanks to Manuel Elías Gutierrez, Giezi Yam and Alma García for their support during the field work.

\section{References}

Altschul, S.F., Gish, W., Miller, W., Myers, E.W., Lipman, D.J., 1990. Basic local alignment search tool. J. Mol. Biol. 215, 403-410.

Baltanás, A., 2001. Candelacypris gen. n. (Crustacea, Ostracoda), a new genus from Iberian saline lakes, with a redescription of Eucypris aragonica. Bull. Soc. Nat. luxemb. 101, 183-192. Bode, S.N.S., Adolfsson, S., Lamatsch, D.K., Martins, M.J.F., Schmit, O., Vandekerkhove, J., 2010. Exceptional cryptic diversity and multiple origins of parthenogenesis in a freshwater ostracod. Mol. Phylogenet. Evol. 54, 542-552.

Broodbakker, N.W., 1982. The genus Heterocypris in the West Indies. Part I. Taxonomic characters. Bijd. Dierkunde 52, 207-227. 
Broodbakker, N.W., Danielopol, D.L., 1982. The chaetotaxy of Cypridacea (Crustacea, Ostracoda) limbs: proposal for a descriptive model. Bijd. Dierkunde 52, 103-120.

Darriba, D., Taboada, G.L., Doallo, R., Posada, D., 2012. jModelTest 2: more models, new heuristics and parallel computing. Nat. Methods 9, 772.

Díaz, A.R., Martens, K., 2014. On Argentocypris sara gen. nov., sp. nov. (ostracoda) from the Patagonian wetlands of Argentina. Crustaceana 87, 513-530.

Felsenstein, J., 1985. Confidence limits on phylogenies: an approach using the bootstrap. Evolution 39, 783-791.

Furtos, N., 1936. On the Ostracoda from the cenotes of Yucatan and vicinity. Carnegie Inst. Wash. 457, 89-115.

Garm, A., 2004. Revising the definition of the crustacean seta and setal classification systems based on examinations of the mouth part setae of seven species of decapods. Zool. J. Linn. Soc. $142,233-252$.

Guindon, S., Gascuel, O., 2003. A simple, fast and accurate algorith to estimate large phylogenies by maximum-likelihood. Syst. Biol. 52, 696-704.

Hills, D.M., Dixon, M.T., 1991. Ribosomal DNA: Molecular Evolution and Phylogenetic Inference. Q. Rev. Biol. 66, 411-453.

Karanovic, I., 2008. Three interesting Cyprididae (Ostracoda) from Western Australia. Rec. South Aust. Mus. 24, 267-287.

Karanovic, I., 2012. Recent freshwater ostracods of the world. Crustacea, Ostracoda, Podocopida. Springer, Berlin.

Kempf, E.K., 1980a. Index and bibliography of nonmarine Ostracoda. Index A. Sonderver. Geolog. Inst. Univ. Köln 35, 1-188. 
Kempf, E.K., 1980b. Index and bibliography of nonmarine Ostracoda. Index B. Sonderver. Geolog. Inst. Univ. Köln 36, 1-180.

Kempf, E.K., 1980c. Index and bibliography of nonmarine Ostracoda. Index C. Sonderver. Geolog. Inst. Univ. Köln 37, 1-204.

Kempf, E.K., 1980d. Index and bibliography of nonmarine Ostracoda. Bibliography A.

Sonderver. Geolog. Inst. Univ. Köln 38, 1-186.

Kempf, E.K., 1991. Index and bibliography of nonmarine Ostracoda. Bibliography B. Sonderver. Geolog. Inst. Univ. Köln 77, 1-238.

Kempf, E.K., 1997a. Index and bibliography of nonmarine Ostracoda. Index A, supplement. Sonderver. Geolog. Inst. Univ. Köln 109, 1-142.

Kempf, E.K., 1997b. Index and bibliography of nonmarine Ostracoda. Index B, supplement. Sonderver. Geolog. Inst. Univ. Köln 110, 1-134.

Kempf, E.K., 1997c. Index and bibliography of nonmarine Ostracoda. Index C, supplement. Sonderver. Geolog. Inst. Univ. Köln 111, 1-152.

Kempf, E.K., 1997d. Index and bibliography of nonmarine Ostracoda. Bibliography C. Sonderver. Geolog. Inst. Univ. Köln 112, 1-144.

Keyser, D., 1975. Ostracoden aus den Mangrovegebieten von Südwest-Florida (Crustacea: Ostracoda, Podocopa). Abh. Verh. Naturwiss. Ver. Hamburg 18/19, 255-290.

Hurvich, C.M., Tsai, C.L., 1989. Regression and time series model selection in small samples. Biometrika 76, 297-307.

Kato, C., Li, L., Tamaoka, J., Horikoshi, K., 1997. Molecular analyses of the sediment of the 11000-m deep Mariana Trench. Extremophiles 1, 117-123.

Kong, Q., Karanovic, I., Yu, N., 2014. Phylogeny of the genus Chrissia (Ostracoda: Cyprididae) with description of a new species from China. J. Crust. Biol. 34, 782-794. 
Martens, K., 1986. Taxonomic revision of the subfamily Megalocypridinae Rome, 1965

(Crustacea, Ostracoda). Verhandelingen van de Koninklijke Academie voor Wetenschappen, Letteren en schone Kunsten van Belgie, Klasse Der Wetenschappen 48, 1-138.

Martens, K., 1989. On the systematic position of the Eucypris clavata-group, with a description of Trajancypris gen. nov. (Crustacea, Ostracoda). Arch. Hydrobiol. 2, 227-251.

Martens, K., 1990. Taxonomic revision of African Cypridini. Part I: the genera Cypris O.F. Muller, Pseudocypris Daday and Globocypris Klie (Crustacea, Ostracoda). Bull. Inst. R. Sci. Nat. Belg. Biol. 60, 127-172.

Martens, K., 1992. Taxonomic revision of African Cypridini. Part II. Description of Ramotha gen. nov. Ann. S. Afr. Mus. 102, 91-130.

Martens, K., 2001. Taxonomy of the Herpetocypridinae (Crustacea, Ostracoda). Crustaceana 74, 295-308.

Martens, K., Ortal, O., Meisch, C., 1992. The ostracod fauna of Manilla pool (Jerusalem, Israel), (Crustacea, Ostracoda). Zool. Middle east 7, 95-114.

Martens, K., Savatenalinton, S., 2011. A subjective checklist of the Recent, free-living, nonmarine Ostracoda (Crustacea). Zootaxa 2855, 1-79.

Martens, K., Schön, I., Meisch, C., Jorne, D.J., 2008. Global diversity of ostracods (Ostracoda, Crustacea) in freshwater. Hydrobiologia 595, 185-193.

Meisch, C., 1996. Contribution to the taxonomy of Pseudocandona and four related genera, with the description of Schellencandona nov. gen., a list of the Candoninae genera, and a key to the European genera of the subfamily (Crustacea, Ostracoda). Bull. Soc. Natur. luxemb. 97, 211237. 
Meisch, C., 2000. Freshwater Ostracoda of Western and Central Europe, in: Schwoerbel, J., Zwick, P. (Eds.), Süßwasserfauna von Mitteleuropa. Spektrum Akademischer Verlag, Gustav Fischer, Berlin, pp. 1-522.

Meisch, C., 2007. On the origin of the putative furca of the Ostracoda (Crustacea). Hydrobiologia $585,181-200$.

Rodríguez, F., Oliver, J.F., Marín, A., Medina, J.R., 1990. The general stochastic model of nucleotide substitutions. J. Theor. Biol. 142, 485-501.

Rossi, V., Gandolfi, A., Balardi, F., Bellavere, C., Menozzi, P., 2007. Phylogenetic relationships of coexisting Heterocypris (Crustacea, Ostracoda) lineages with different reproductive modes from Lampedusa Island (Italy). Mol. Phylogenet. Evol. 44, 1273-1283.

Rossi, V., Menozzi, P., 1990. The clonal ecology of Heterocypris incongruens (Ostracoda). Oikos 57, 388-398.

Savatenalinton, S., Martens, K., 2009. Generic revision of Cypricercinae McKenzie, 1971 (Crustacea, Ostracoda), with the description of three new genera and one new species and a phylogenetic analysis of the subfamily. Hydrobiologia 632, 1-48.

Tamura, K., Stecher, G., Peterson, D., Filipski, A., Kumar, S., 2013. MEGA6: Molecular Evolutionary Genetics Analysis Version 6.0. Mol. Biol. Evol. 30, 2725-2729.

Thompson, J.D., Higgins, D.G., Gibson, T.J., 1994. Clustal-W - improving the sensitivity of progressive multiple sequence alignment through sequence weighting, position-specific gap penalties and weight matrix choice. Nucleic. Acids. Res. 22, 4673-4680.

Sars, G.O., 1924. The freshwater Entomostraca of the Cape Province (Union of South Africa) Ostracoda. Ann. S. Afr. Mus. 20, 105-193.

Swofford, D.L., 2002. PAUP*. Phylogenetic Analysis Using Parsimony (*and Other Methods) (Version 4) [Computer Software]. Sunderland: Sinauer Associates. 
Yamaguchi, E., 2003. Morphological evolution of cytherocopine ostracods inferred from 18s ribosomal DNA sequences. J.Crust. Biol. 23, 131-153.

Yamaguchi, S., Endo, K., 2003. Molecular phylogeny of Ostracoda (Crustacea) inferred from 18S ribosomal DNA sequences: implication for its origin and diversification. Mar. Biol. 143, 2338.

Yu, N., Zhao, M., Chen, L., Yang, P., 2005. Preliminary Study on Phylogenetic Relationships of Cypridocopina (Ostracoda: Podocopida) Based on 18S rDNA Sequences. J. East China Norm. Univ. Natur. Sci. 4, 78-86. 
Figure captions

Fig. 1. Map of the study area. (a) Collection sites of Manuelcypris chetumalensis n. sp.; (b) Collection sites of Manuelcypris tabascena $\mathrm{n} . \mathrm{sp}$.

Fig. 2. Manuelcypris chetumalensis n. sp., SEM. Right valve adult male: (A) internal view, (B) Anterior margin internal view, (C) antero-ventral margin internal view, (D) Postero-ventral margin internal view.

Fig. 3. Manuelcypris chetumalensis n. sp., SEM. Adult female: (A)Left valve outside view, (B) Right valve internal view, (C, D) Dorsal margin internal view, showing the hinge structure (E) Muscle scars imprints, $(\mathrm{F})$ Surface sensilla exiting from rimmed pores.

Fig. 4. Manuelcypris chetumalensis n. sp., SEM: (A)carapace dorsal view, (B) carapace ventral view, (C) carapace antero dorsally showing the differences in carapace size and overlapping, (D) anterior marginal pore canals ending with setae, $(\mathrm{E})$ carapace ventral view, right valve overlapping left valve ventrally (F) Carapace anteriorly showing carapace overlaping. Fig. 5. Manuelcypris chetumalensis n. sp.. Adult male: (A) Left valve internal view, (B) Right internal view, (C) A1, (D) Respiratory plate, arrow showing distal short setae, (E) UR, (F) Md and Mdp. Scale bars $=0.05 \mathrm{~mm}$.

Fig. 6. Manuelcypris chetumalensis n. sp.. Male: (A) A2; (B) left prehensile palp; (C) Distal section of L7; (D) Hemipenis; (E) Right prehensile palp. Scale bars $=0.05 \mathrm{~mm}$.

Fig. 7. Manuelcypris chetumalensis n. sp.. Female: (A) Left valve internal view; (B) Right valve internal view; (C) Mandible; (D) Antenna: A2; (E) Antennula: A1; (F, G) First thoracopod: L5. Scale bars $=0.05 \mathrm{~mm}$.

Fig. 8. Manuelcypris chetumalensis n. sp.. Female: (A) Mxl; (B) L7; (C) L6; (D) Genital field, arrow showing a distal projection; (E) UR. Scale bars $=0.05 \mathrm{~mm}$. 
Fig. 9. Manuelcypris tabascena n. sp., SEM. Female: (A)Left valve outside view; (B) Right internal view; (C) Left valve anteriorly showing the small wart-like structures; (D) Dorsal margin internal view; (E) Carapace surface with setae exiting from a pore; (F) Muscle scars imprints. Fig. 10. Manuelcypris tabascena n. sp., SEM. Female Right valve: (A) antero-ventrally internal view showing the inner list; (B) postero-ventrally internal view; (C) detail of anterior marginal tubercles; (d) detail of posterior marginal tubercles.

Fig. 11. Manuelcypris tabascena n. sp., Female: Right valve internal view.

Fig. 12. Manuelcypris tabascena n. sp.. Female: (A) Right valve external view; (B) Left valve external view; (C) mandible; (D) Mdp; (E) A2; (F) Mxp; (G) teeth bristle of the third endite of maxilla. Scale bars $=0.1 \mathrm{~mm}$.

Fig. 13. Manuelcypris tabascena n. sp.. Female: (A) A1; (B) L5; (C) L7; (D) L6; (E)UR and genital field; (F)UR attachment. Scale bar=0.1mm

Fig. 14. Eucypris cisternina Furtos, 1936. Female: Right valve external view.

Fig. 15. Eucypris cisternina Furtos, 1936. Female: (A) Right valve internal view; (B) Left valve internal view; (C) respiratory plate; (D) UR; (E) A2. Scale bars $=0.05 \mathrm{~mm}$.

Fig. 16. Manuelcypris cisternina (Furtos, 1936) comb. nov.. Female: (A) A1; (B) Mandible; (C) Mdp. Scale bars $=0.05 \mathrm{~mm}$

Fig. 17. Manuelcypris cisternina (Furtos, 1936) comb. nov.. Female: (A) L6; (B) L7; (C) L5, arrow is showing additional seta on endopodite. Scale bars $=0.05 \mathrm{~mm}$.

Fig. 18. Molecular analysis of taxonomic position of Manuelcypris n. gen. using the 18S rDNA gen (A) Maximum Parsimony tree topology; (B) Maximum Likelihood tree topology. Numbers above branches represent bootstrap values. 
Fig. 19. Molecular analysis of taxonomic position of Manuelcypris $\mathrm{n}$. gen.using the 28S rDNA, (A) Maximum Parsimony tree topology; (B) Maximum Likelihood tree topology. Numbers above branches represent bootstrap values. 
Table 1. Summary of the molecular analyses results

\begin{tabular}{|l|l|l|l|l|l|l|l|l|}
\hline marker & $\begin{array}{l}\text { L of } \\
\text { alignment }\end{array}$ & $\begin{array}{l}\text { constant } \\
\text { characters }\end{array}$ & $\begin{array}{l}\text { parsimony } \\
\text { informative }\end{array}$ & $\begin{array}{l}\text { parsimony } \\
\text { uninformative }\end{array}$ & $\begin{array}{l}\text { no of most } \\
\text { parsimonious } \\
\text { trees }\end{array}$ & $\begin{array}{l}\text { L of } \\
\text { tree }\end{array}$ & $\begin{array}{l}\text { consistency } \\
\text { index }\end{array}$ & $\begin{array}{l}\text { retention } \\
\text { index }\end{array}$ \\
\hline $\begin{array}{l}18 \mathrm{~S} \\
\text { rDNA }\end{array}$ & 1660 & 1418 & 140 & 102 & 1 & 392 & 0.769 & 0.769 \\
\hline $\begin{array}{l}28 S \\
\text { rDNA }\end{array}$ & 1561 & 1220 & 240 & 101 & 1 & 722 & 0.632 & 0.682 \\
\hline
\end{tabular}




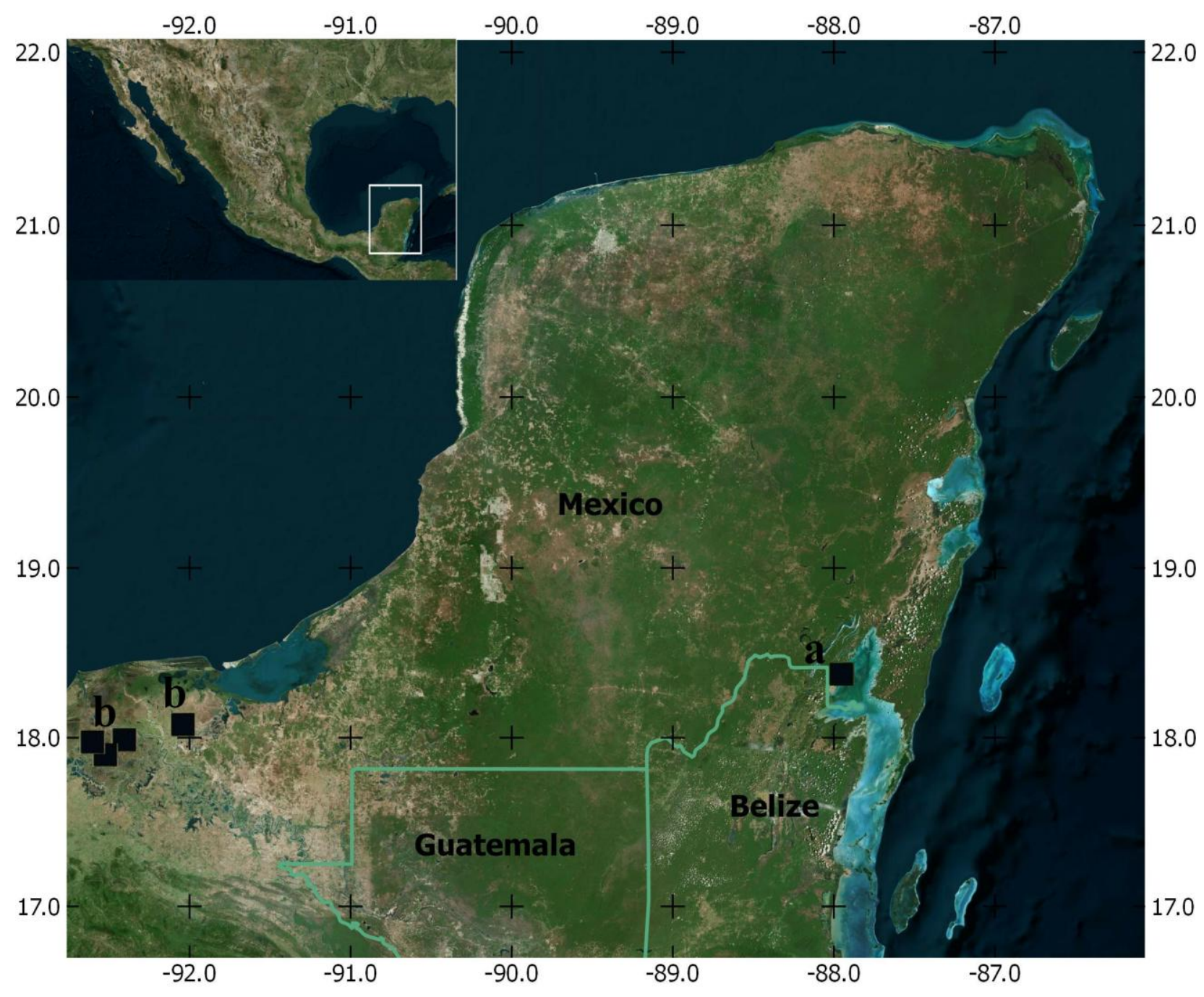




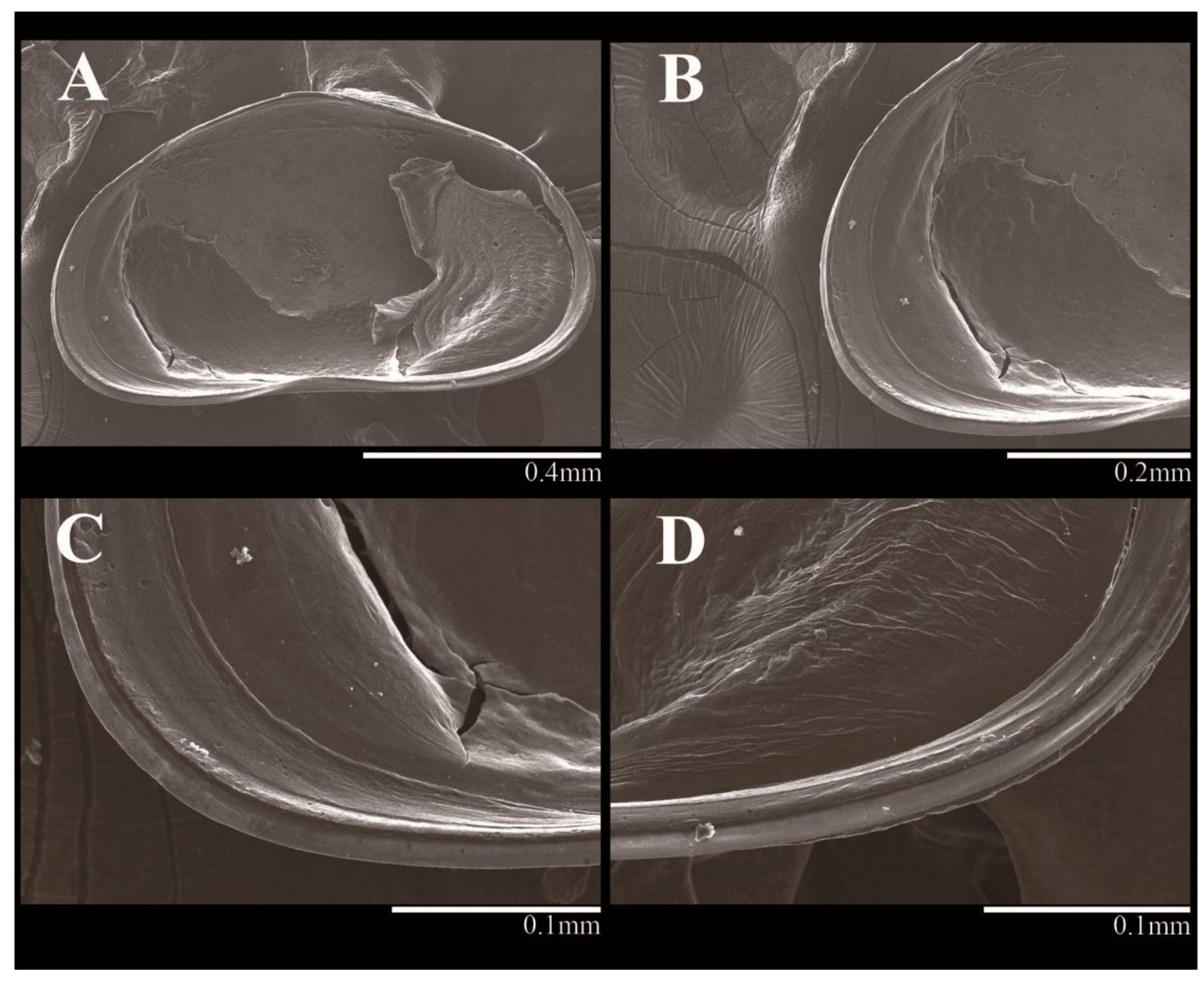




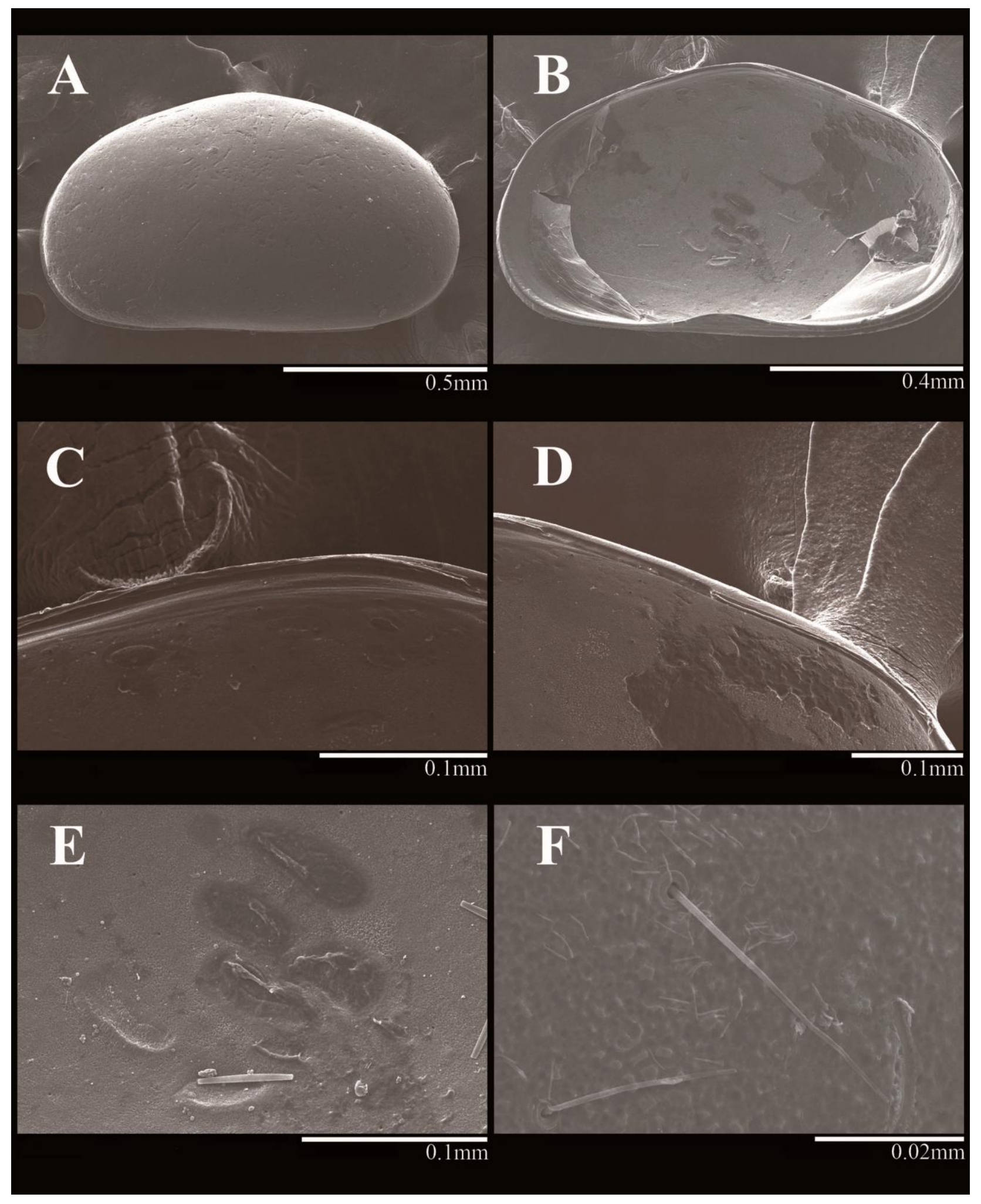




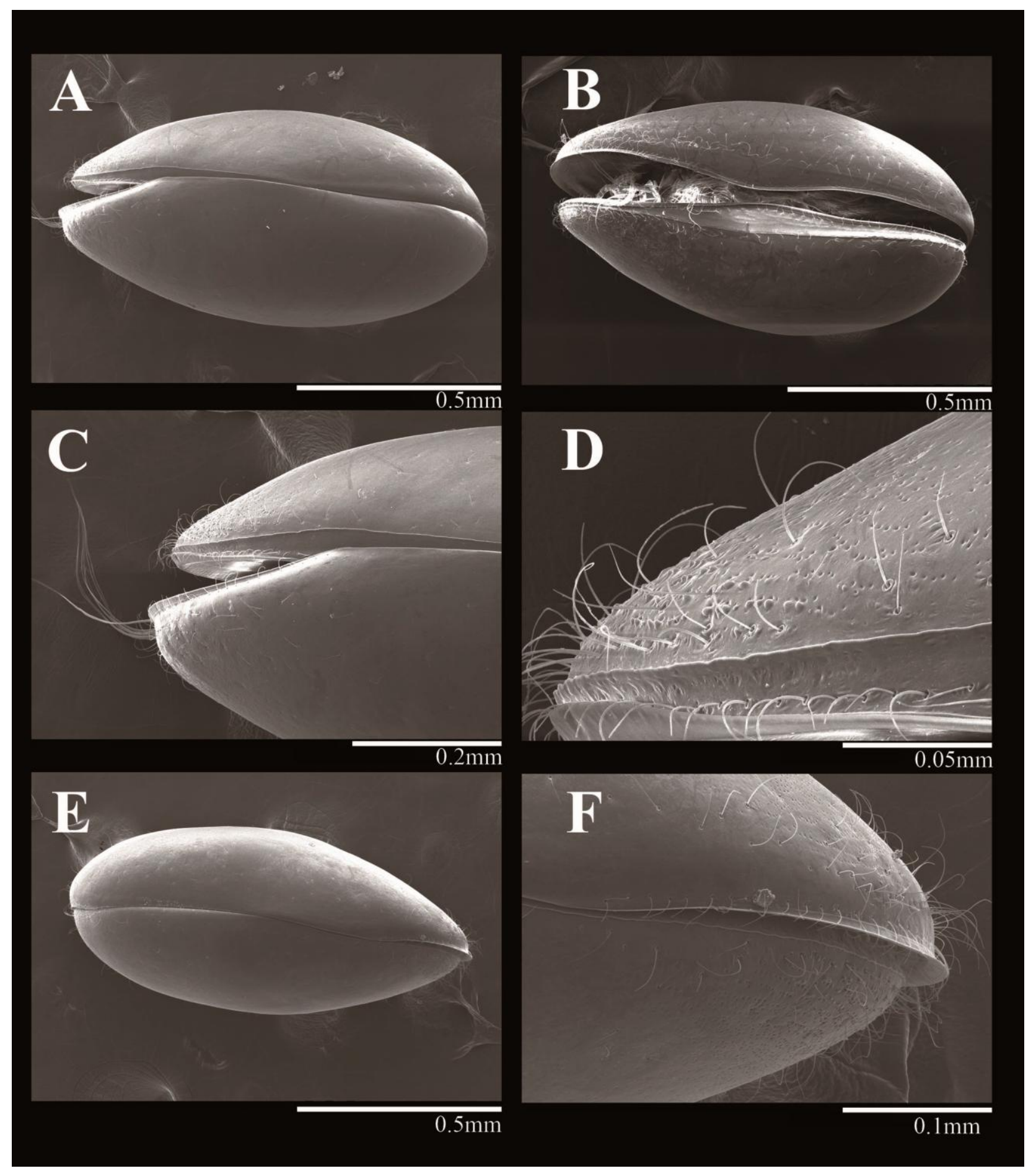




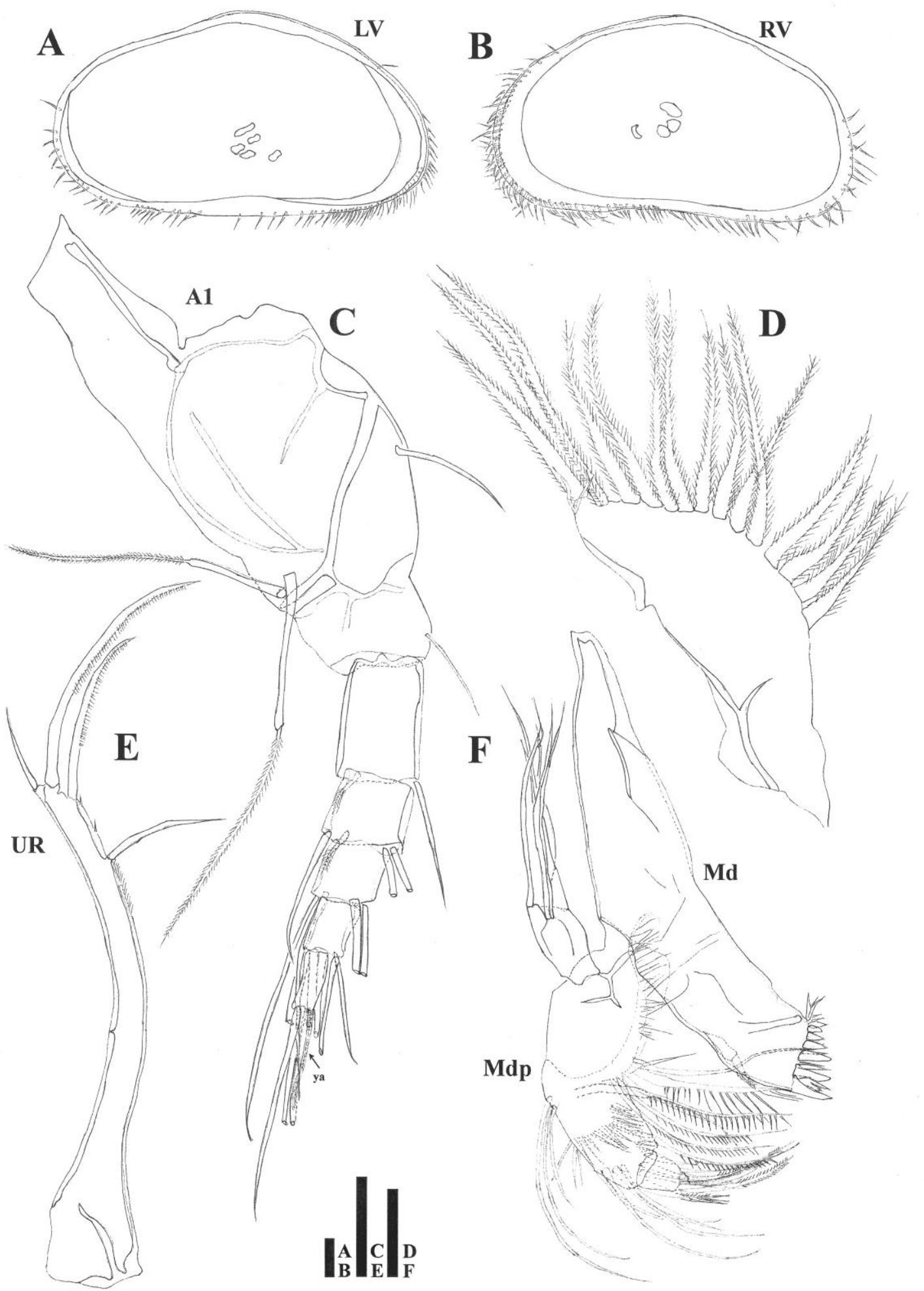




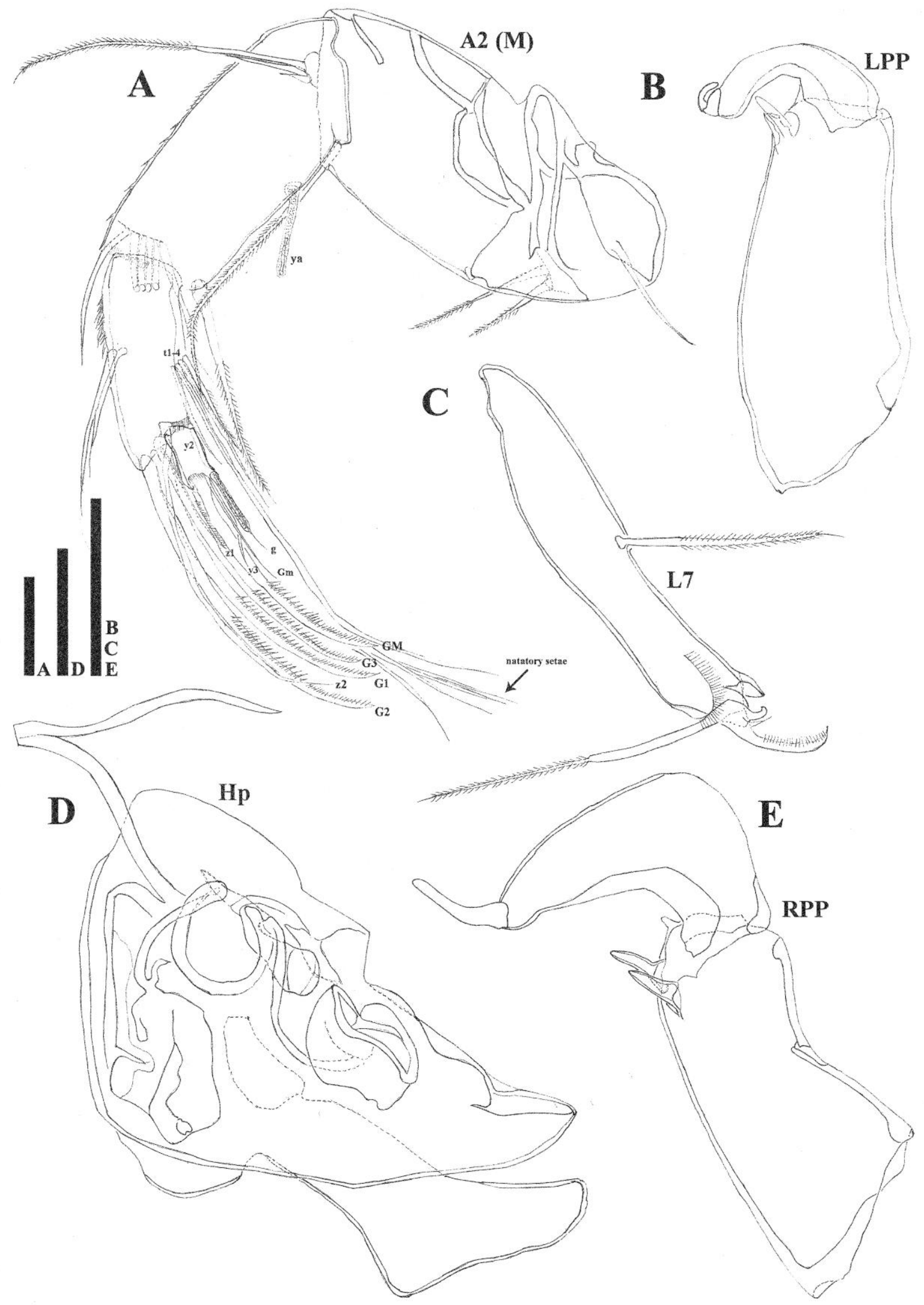




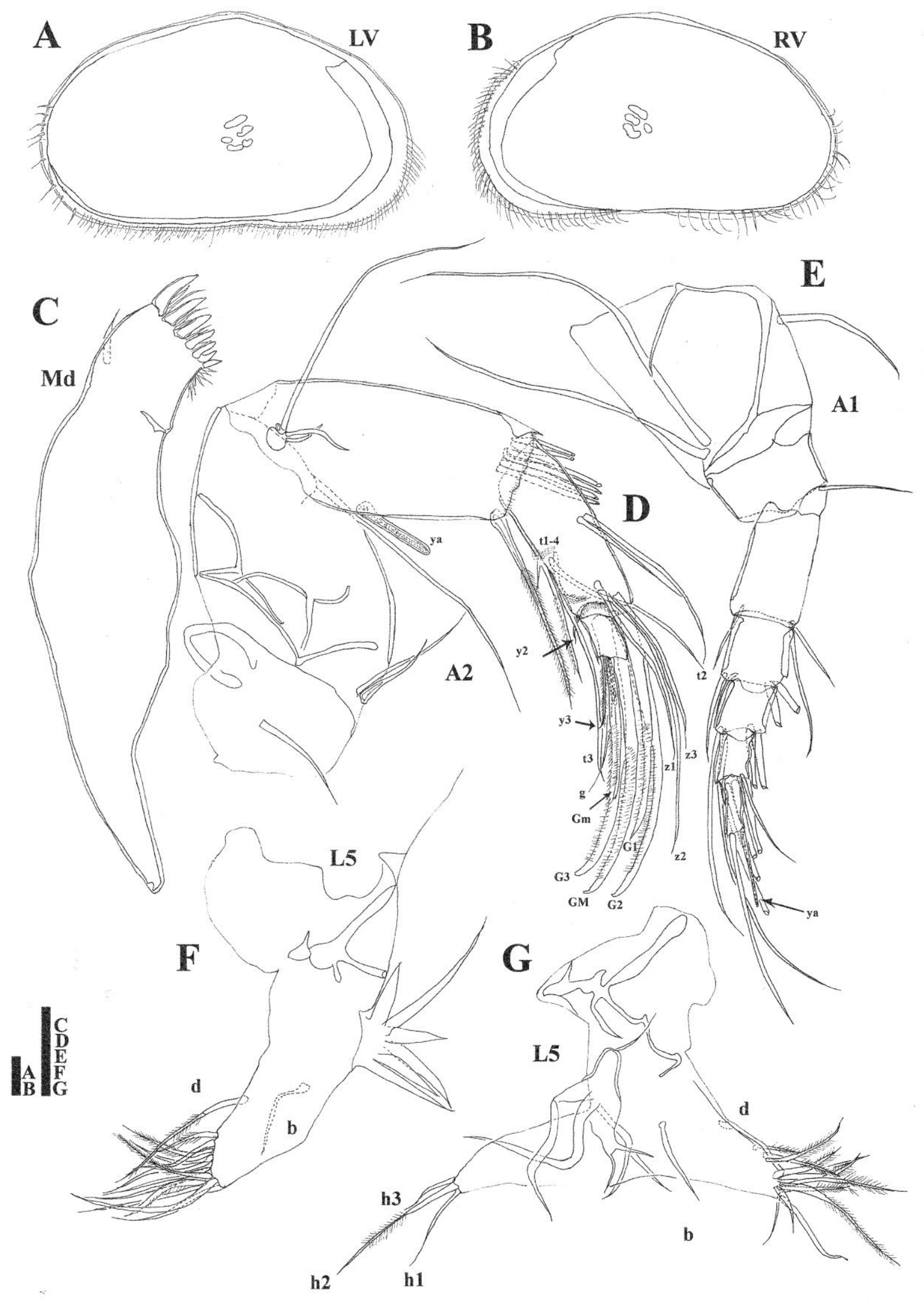




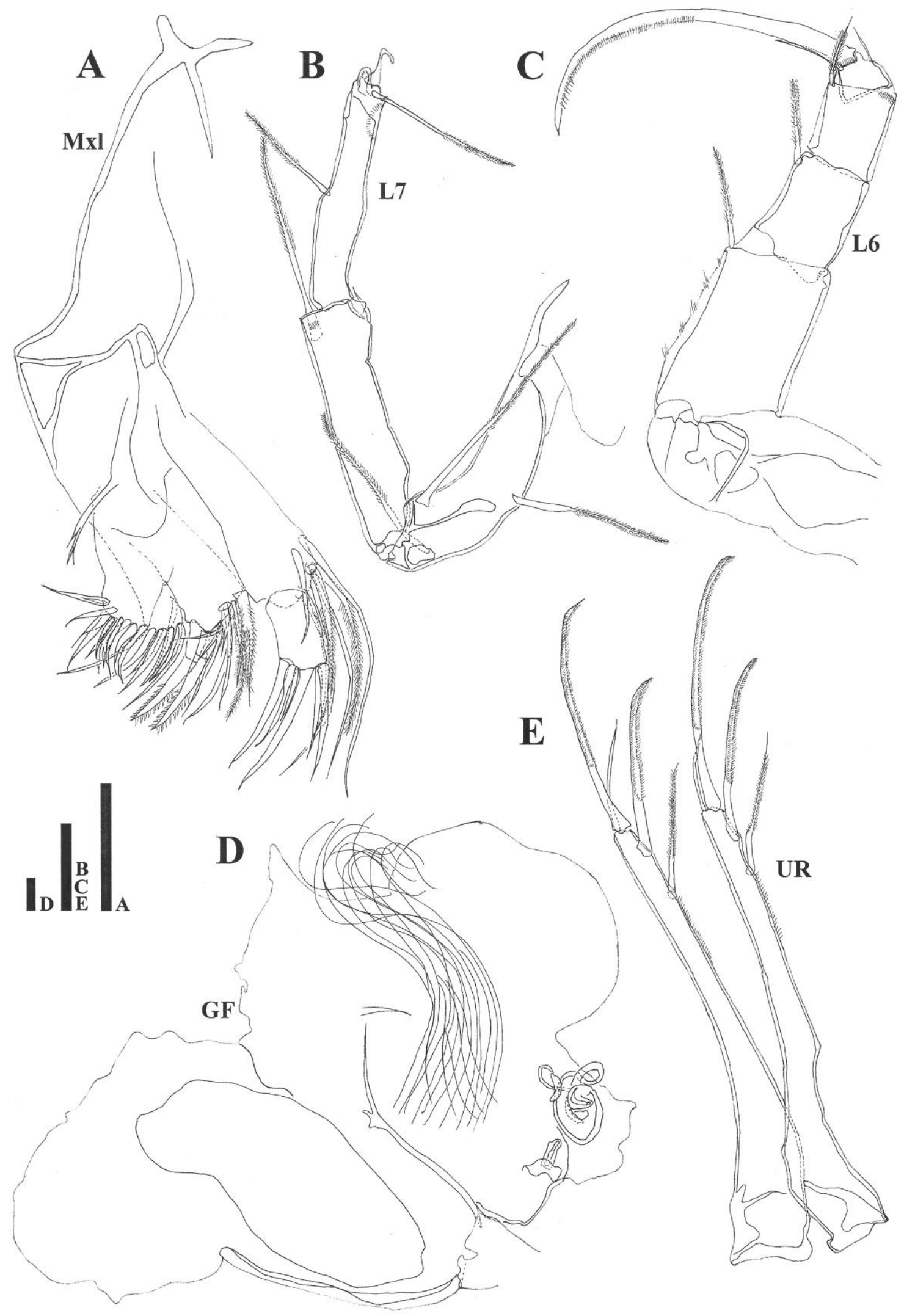



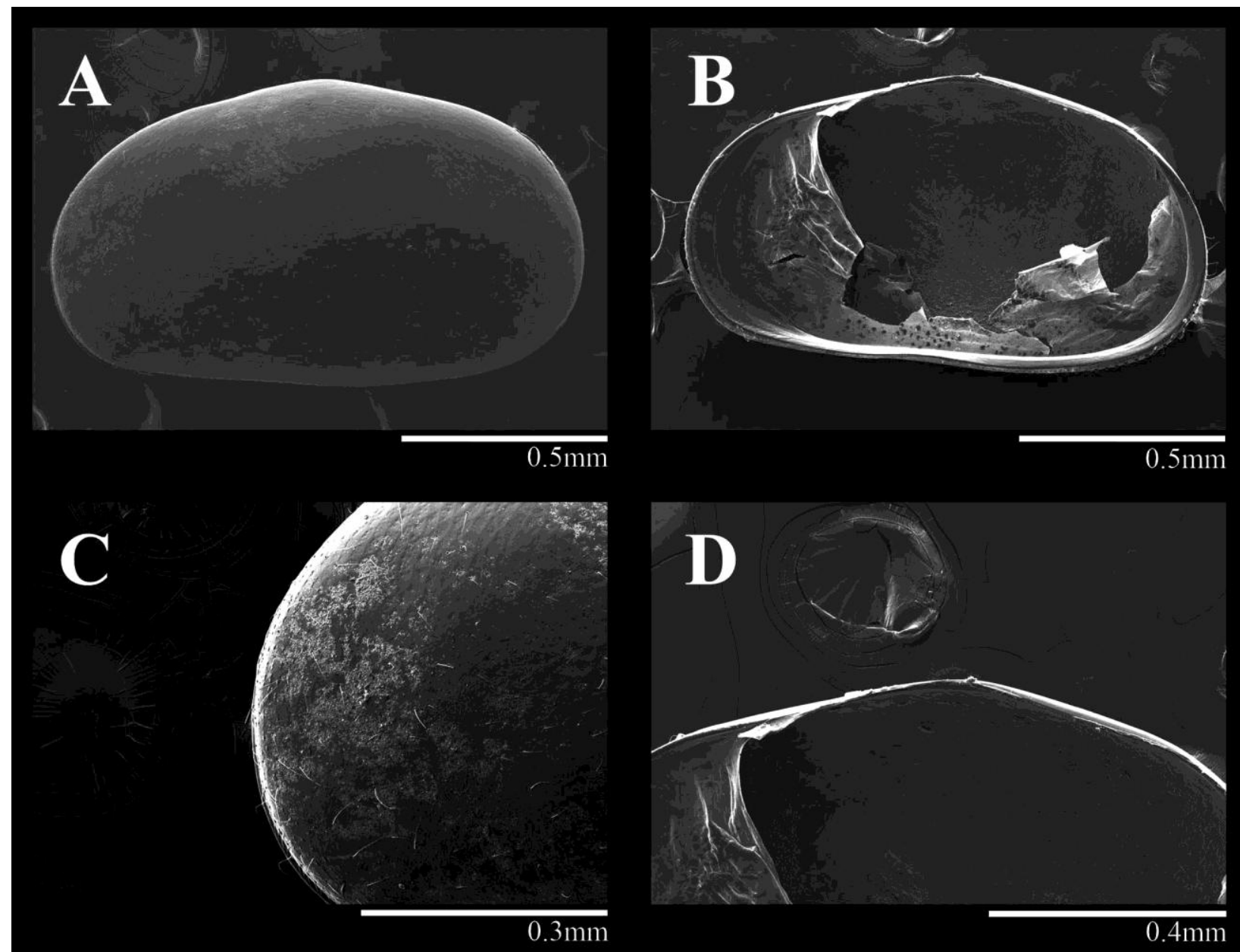

E

F

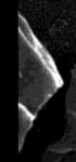




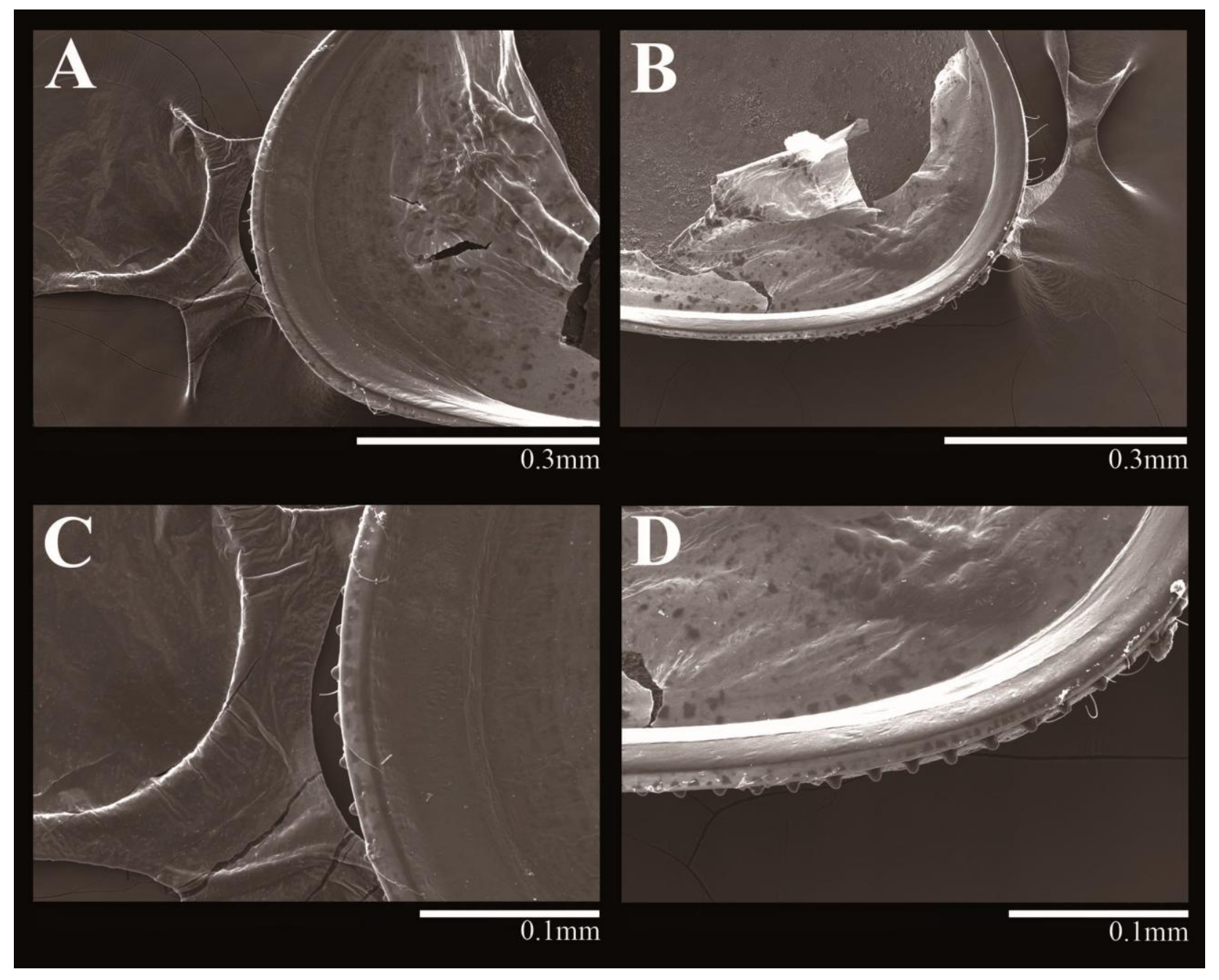




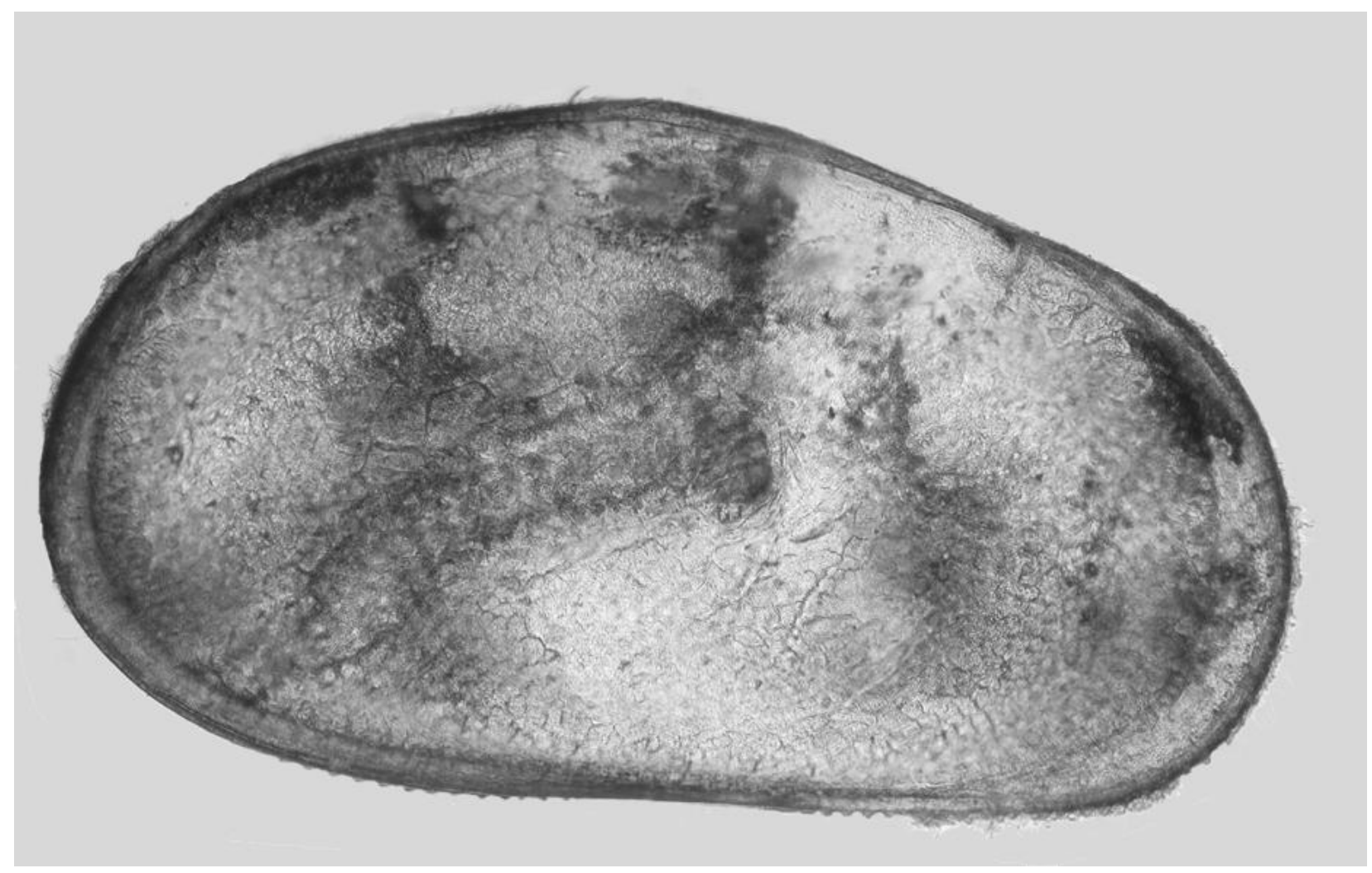




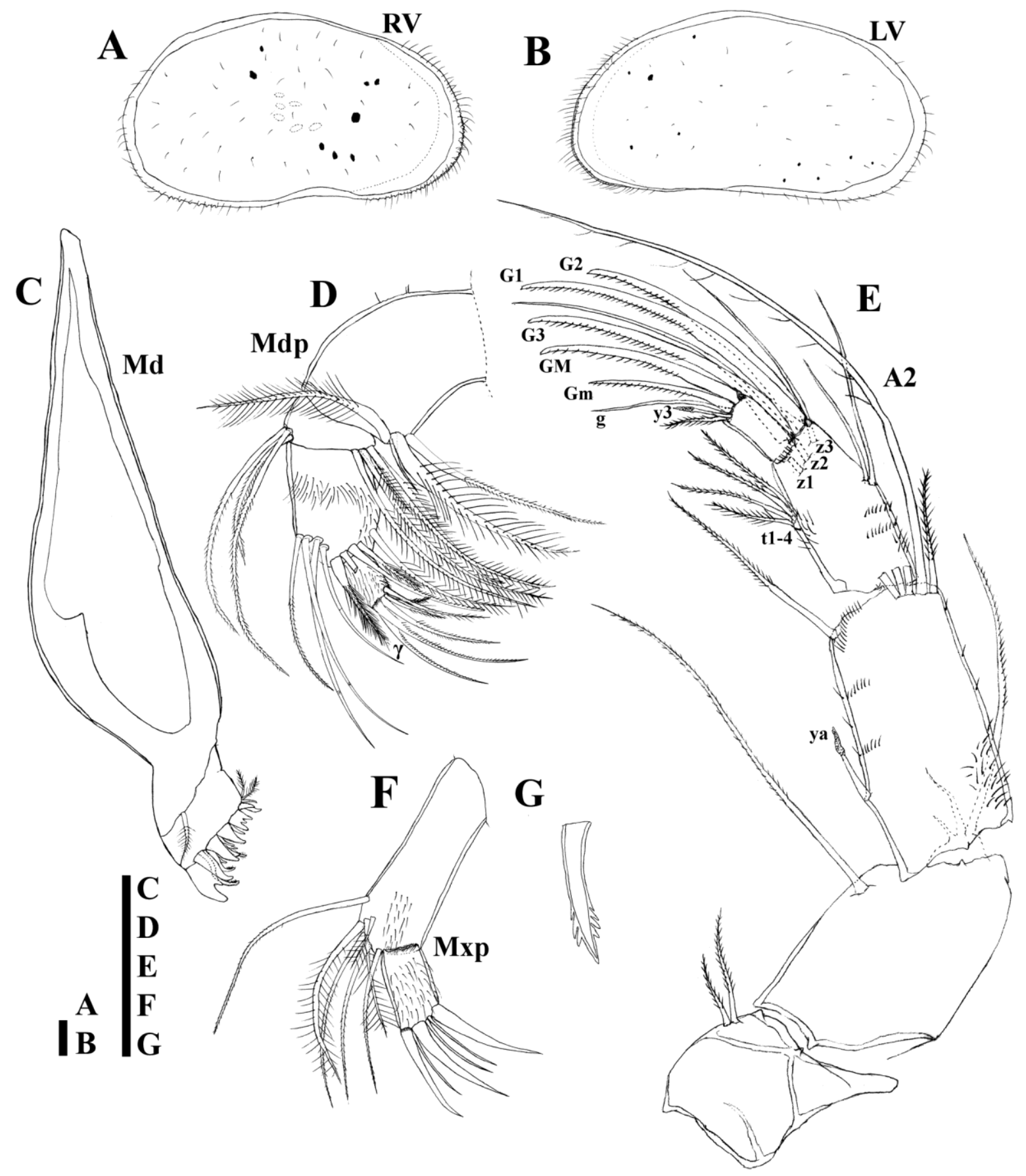




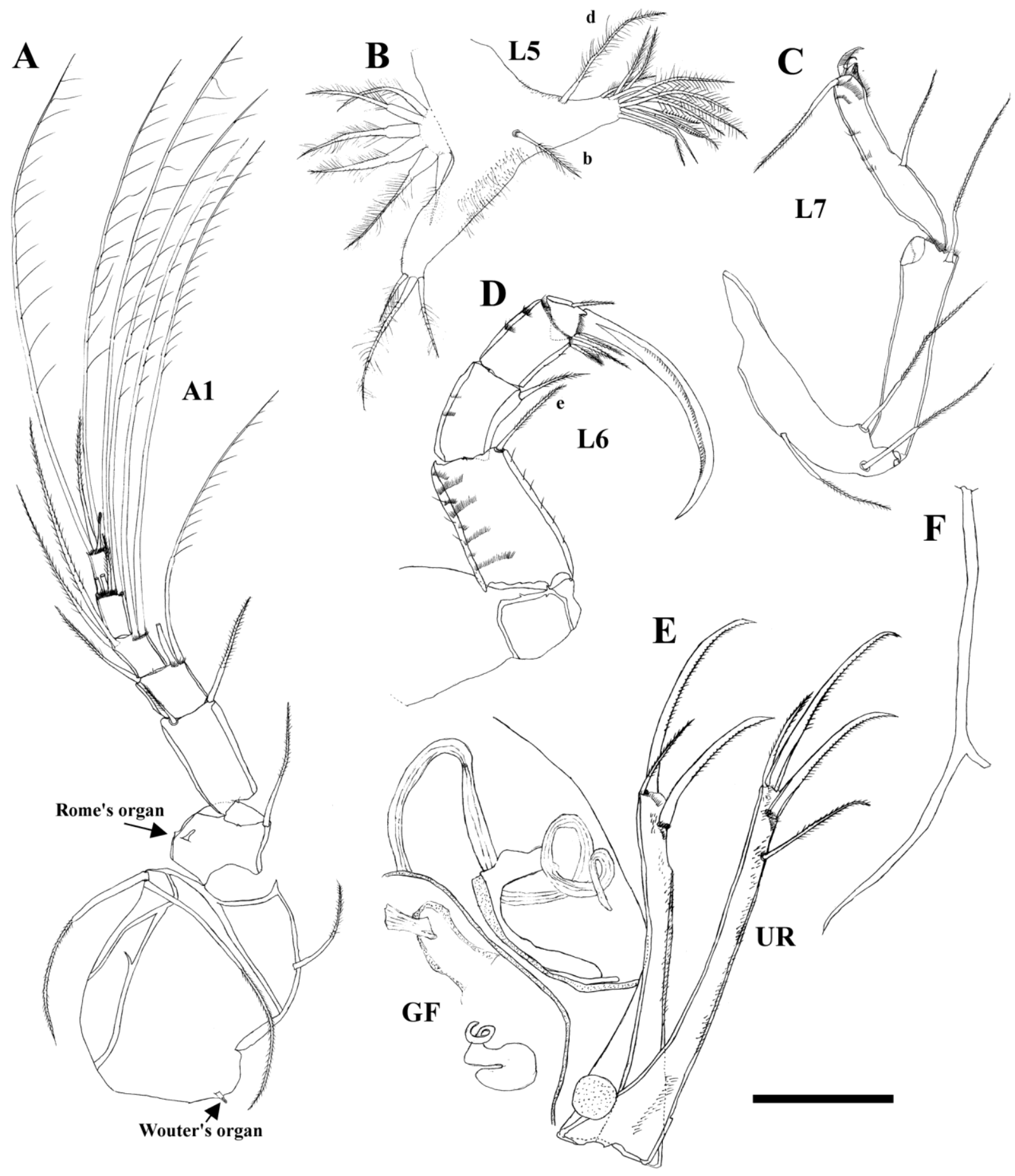




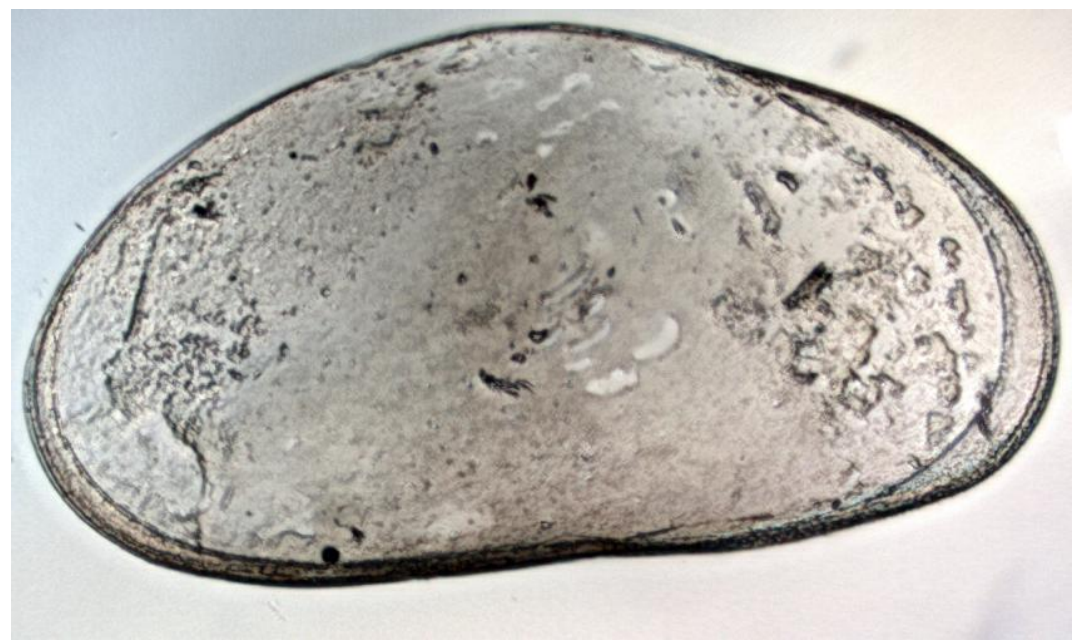



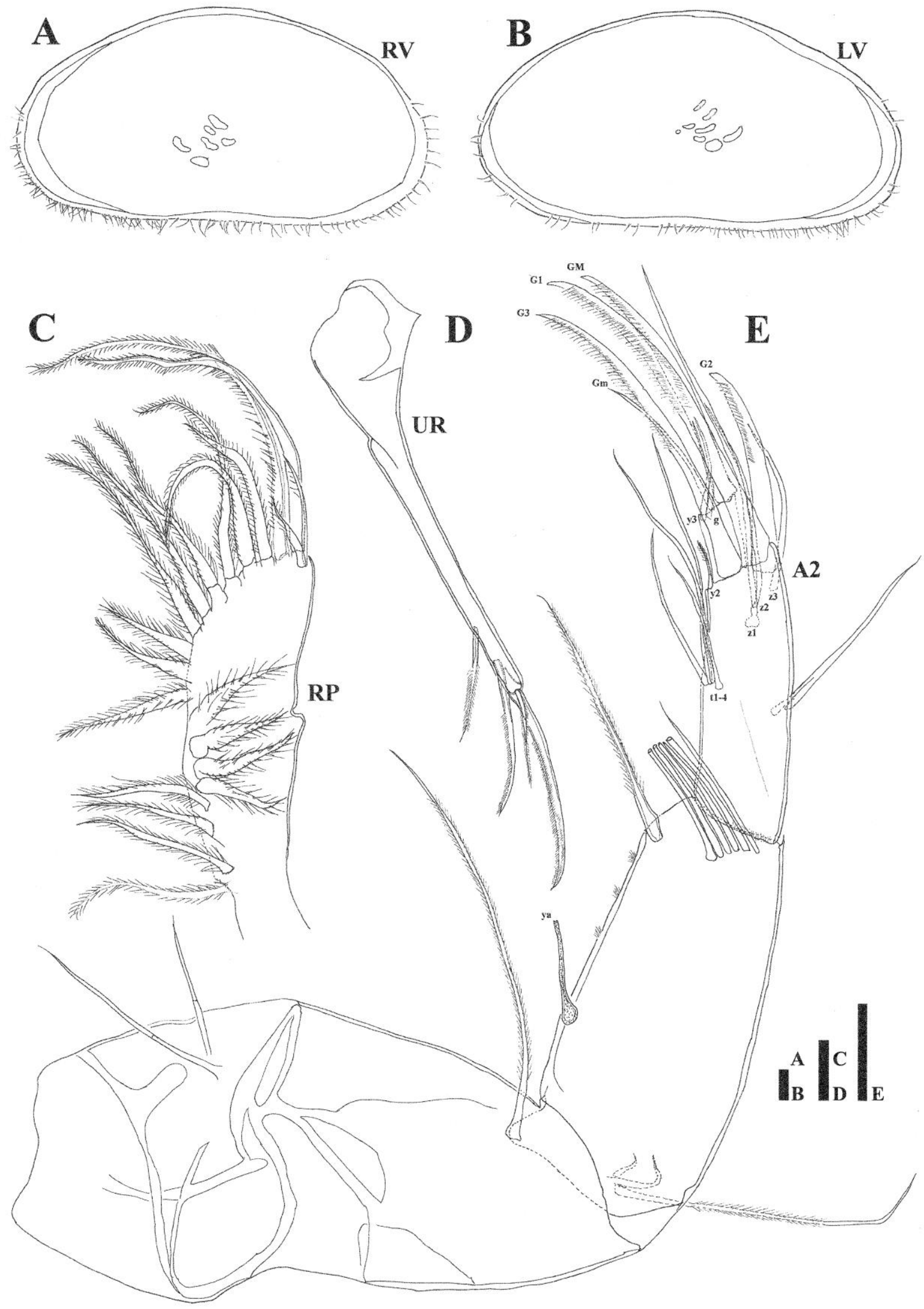


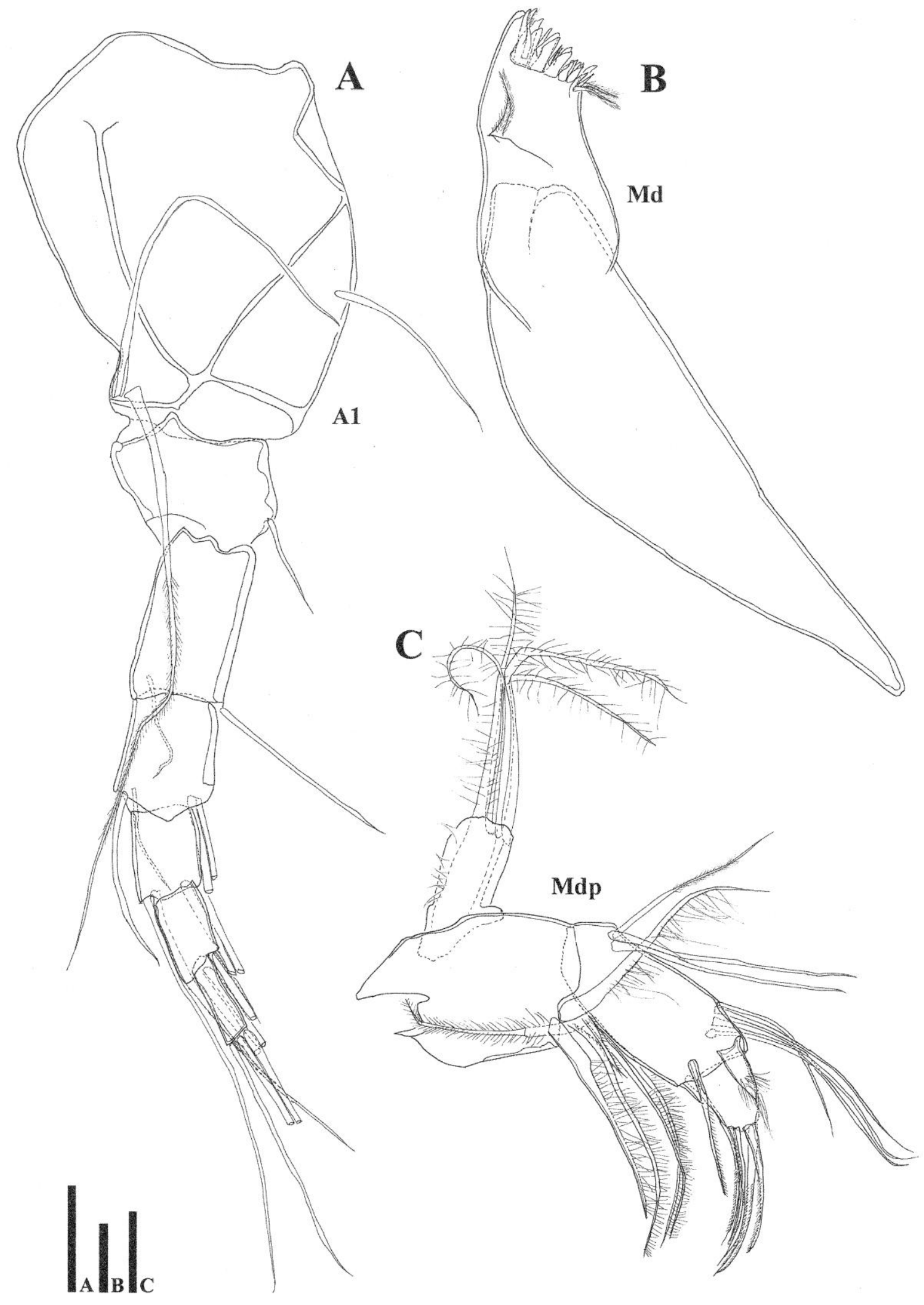




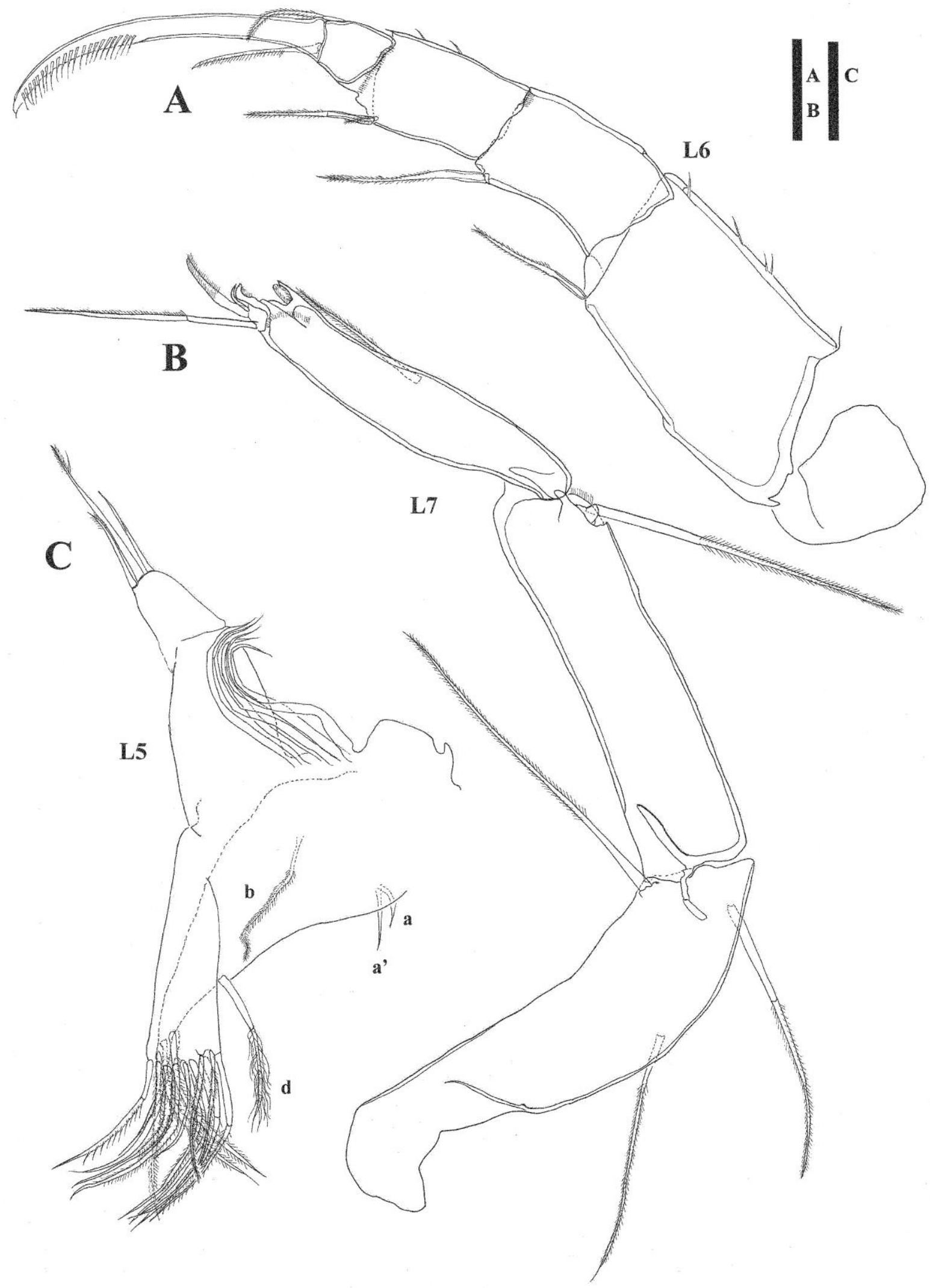




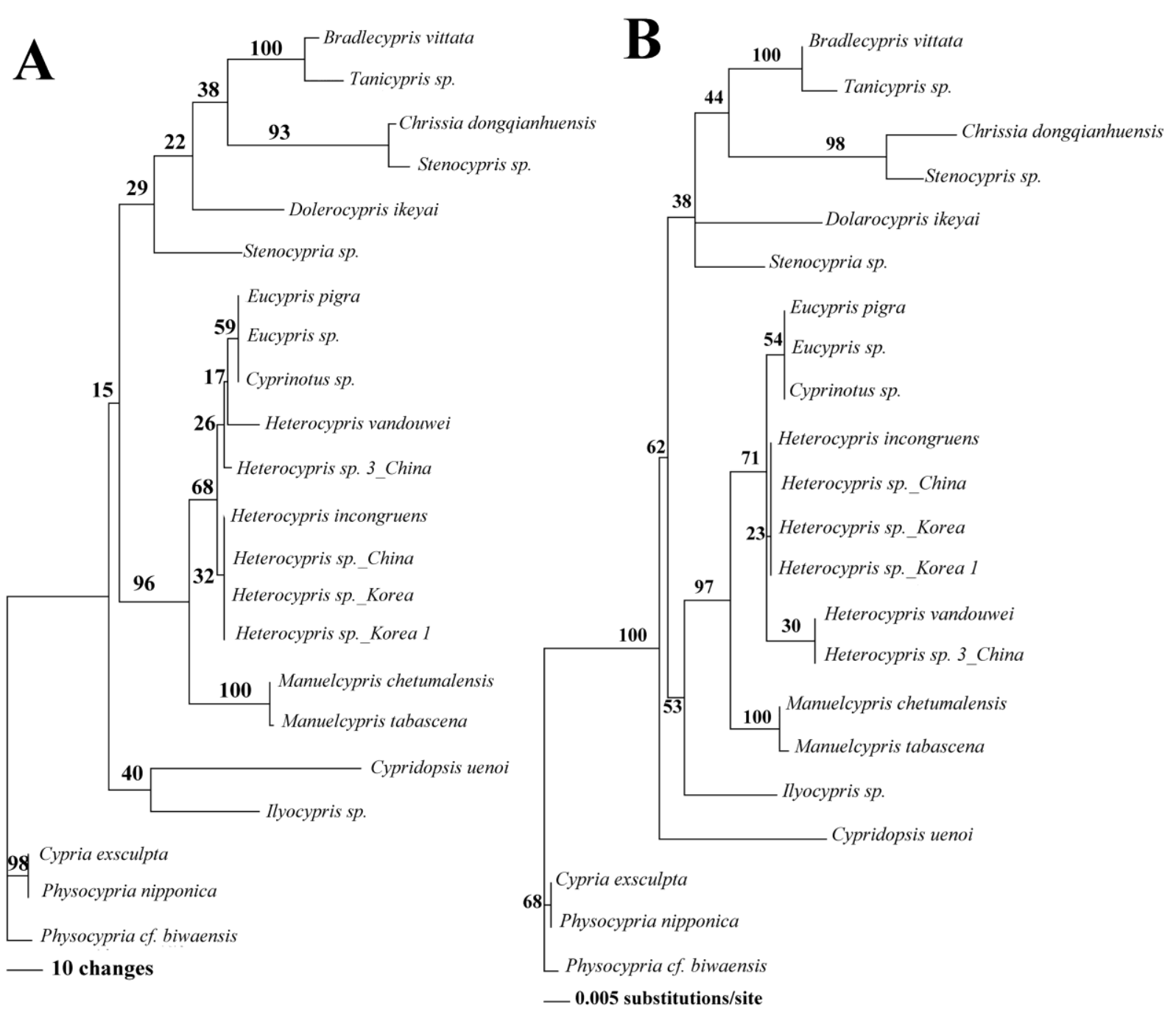




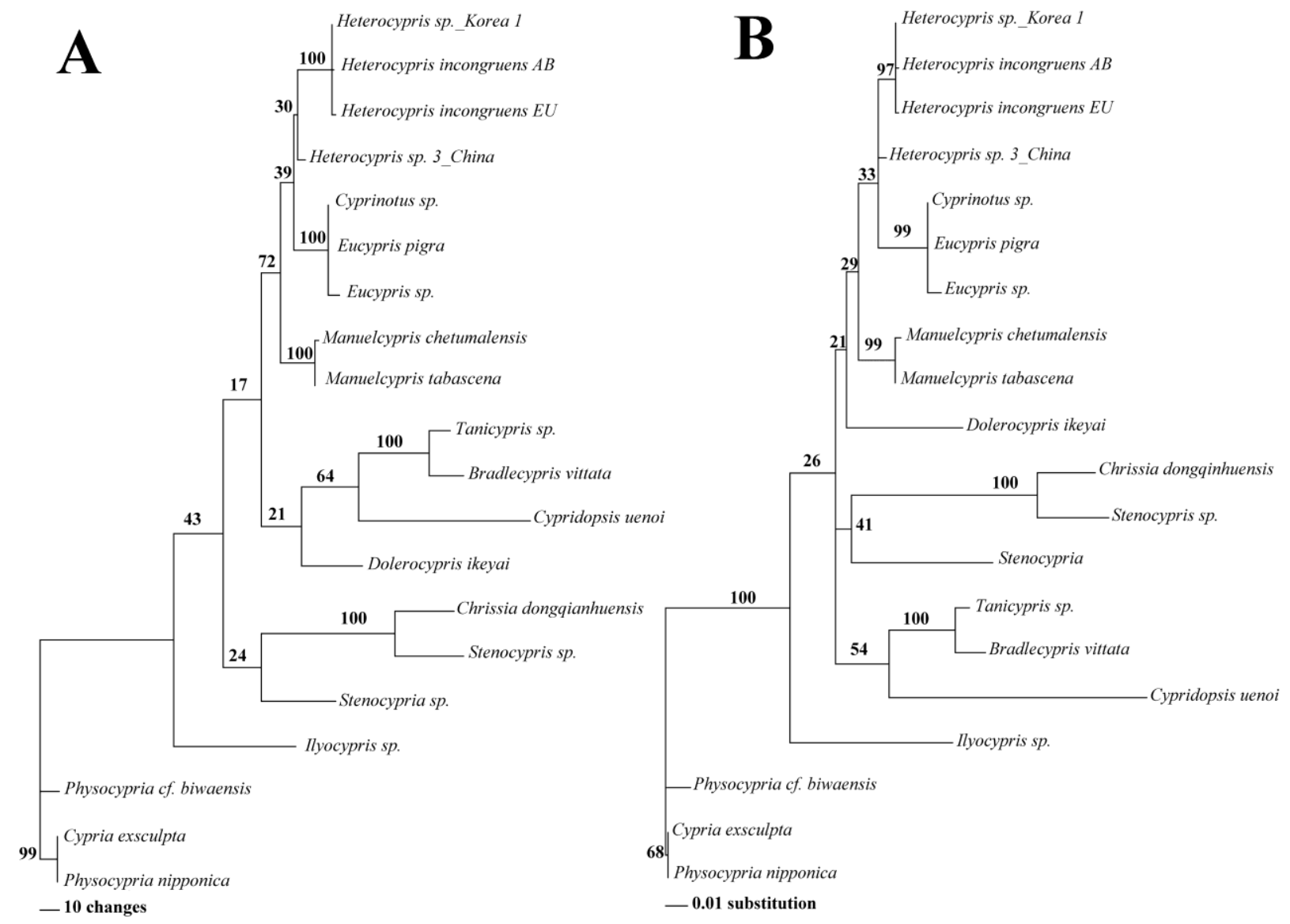

